\title{
Assessment of Nitrogen as an Atmosphere for Dry Storage of Spent LWR Fuel
}

September 1985

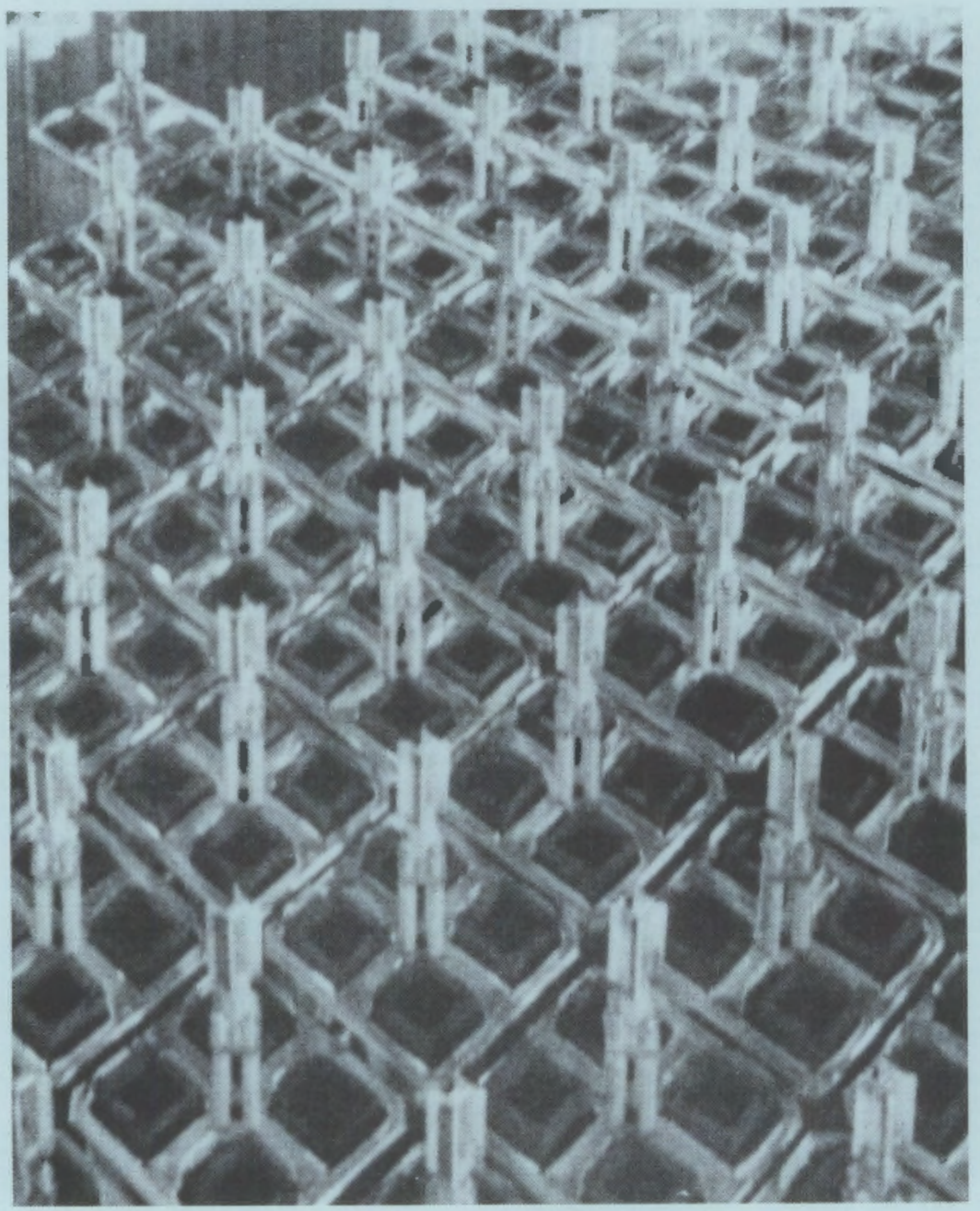

Prepared for the U.S. Department of Energy under Contract DE-AC06-76RLO 1830

Pacific Northwest Laboratory Operated for the U.S. Department of Energy by Battelle Memorial Institute 


\title{
DISCLAIMER
}

This report was prepared as an account of work sponsored by an agency of the United States Government. Neither the United States Government nor any agency thereof, nor any of their employees, makes any warranty, express or implied, or assumes any legal liability or responsibility for the accuracy, completeness, or usefulness of any information, apparatus, product, or process disclosed, or represents that its use would not infringe privately owned rights. Reference herein to any specific commercial product, process, or service by trade name, trademark, manufacturer, or otherwise, does not necessarily constitute or imply its endorsement, recommendation, or favoring by the United States Government or any agency thereof. The views and opinions of authors expressed herein do not necessarily state or reflect those of the United States Government or any agency thereof.

\author{
PACIFIC NORTHWEST LABORATORY \\ operated by \\ BATTELLE \\ for the \\ UNITED STATES DEPARTMENT OF ENERGY \\ under Contract DE-AC06-76RLO 1830
}

\begin{tabular}{|c|c|}
\hline \multicolumn{2}{|c|}{ Printed in the United States of America } \\
\hline \multicolumn{2}{|c|}{ Available from } \\
\hline \multicolumn{2}{|c|}{ National Technical Information Service } \\
\hline \multicolumn{2}{|c|}{ United States Department of Commerce } \\
\hline \multirow{2}{*}{\multicolumn{2}{|c|}{$\begin{array}{c}5285 \text { Port Royal Road } \\
\text { Springfield, Virginia } 22161\end{array}$}} \\
\hline & \\
\hline \multirow{2}{*}{\multicolumn{2}{|c|}{$\begin{array}{l}\text { NTIS Price Codes } \\
\text { Microfiche } A 01\end{array}$}} \\
\hline & \\
\hline \multicolumn{2}{|c|}{ Printed Copy } \\
\hline & Price \\
\hline Pages & Codes \\
\hline 001-025 & $\wedge 02$ \\
\hline 026-050 & A03 \\
\hline 057-075 & A04 \\
\hline 076-100 & A05 \\
\hline $101-125$ & A06 \\
\hline $126-150$ & A07 \\
\hline $151-175$ & $A 08$ \\
\hline $176-200$ & A09 \\
\hline $201-225$ & A010 \\
\hline $226-250$ & A011 \\
\hline $251-275$ & A012 \\
\hline $276-300$ & $A 013$ \\
\hline
\end{tabular}


ASSESSMENT OF NITROGEN AS AN ATMOSPHERE FOR DRY STORAGE OF SPENT LWR FUEL

E. R. Gilbert

C. A. Knox

G. D. White

September 1985

Prepared for

the U.S. Department of Energy

under Contract DE-ACO6-76RLO 1830

Pacific Northwest Laboratory

Richland, Washington 99352 


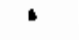
। , 
Appreciation is expressed to D. R. 0lander (University of California), R. E. Einziger (Hanford Engineering Development Laboratory), R. E. Woodley (Hanford Engineering Development Laboratory), J. A. Nevshemal (consultant), and R. W. Lambert (Electric Power Research Institute) for critical reviews of this document and many helpful suggestions. C. Smith and W. Culham of Lawrence Livermore National Laboratory analyzed the cask atmosphere gas samples. A. B. Johnson, Jr., and the Comercial Spent Fuel Management Program Office provided support and technical guidance. S. K. Edler provided technical editing and publication assistance. 



\section{ABSTRACT}

Interim dry storage of spent 1 ight-water reactor (LWR) fuel is being developed as a licensed technology in the United States. Because it is anticipated that license agreements will specify dry storage atmospheres, the behavior of spent LWR fuel in a nitrogen atmosphere during dry storage was investigated. In particular, the thermodynamics of reaction of nitrogen compounds (expected to form in the cover gas during dry storage) and residua! impurities (such as moisture and oxygen) with Zircaloy cladding and with spent fuel at sites of cladding breaches were examined. The kinetics of reaction were not considered because it was assumed that the 20 to 40 years of interim dry storage would be sufficient for reactions to proceed to completion. The primary themodynamic reactants were found to be $\mathrm{N}_{2}, \mathrm{~N}_{2} \mathrm{O}_{2} \mathrm{H}_{2} \mathrm{O}_{2}$, and $\mathrm{O}_{2}$. The evaluation revealed that the limited inventories of these reactants produced by the source terms in hermetically sealed dry storage systems would be too low to cause significant spent fuel degradation. Furthermore, the oxidation of spent fuel to degrading $0 / U$ ratios is unlikely because the oxidation potential in moist nitrogen 1 imits $0 / U$ ratios to values less than $v_{2} 0_{2006}$ (the equilibrium stoichiometric form in equilibrium with moist nitrogen). Tests were performed with bare spent $\mathrm{UO}_{2}$ fuel and nonirradiated $\mathrm{UO}_{2}$ pellets (with no Zircaloy cladding) in a nitrogen atmosphere containing moisture concentrations greater than encountered under dry storage conditions. These tests were performed for at least $1100 \mathrm{~h}$ at temperatures as high as $380^{\circ} \mathrm{C}$, where oxidation reactions proceed in a matter of minutes. No visible degradation was detected, and weight changes were negligible. 


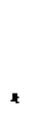

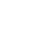

. 
Nitrogen is being considered as an atmosphere for dry storage of spent light-water reactor (LWR) fuel in the United States because of its containability, abundance, thermal properties, and probable low reactivity with spent fuel and storage system components. Although dry storage of spent LWR fuel is not yet licensed in the United States, there is extensive favorable international experience with shipping spent fuel in nitrogen atmospheres. The objective of this evaluation is to determine if reactions between Zircaloy cladding and a nitrogen storage atmosphere and between exposed $\mathrm{UO}_{2}$ at cladding breach sites and a nitrogen storage atmosphere could limit the application of nitrogen for dry storage. The effects of impurities (including residual oxygen, moisture from cask loading operations, moisture released from waterlogged fuel, and radiolysis products) were evaluated.

The thermodynamics for the reactions of zirconium and oxides of uranium with nitrogen compounds that form under conditions of radiolysis were assessed. The assessment showed that oxides of uranium will not react with nitrogen or residual moisture at expected dry storage temperatures. However, oxidizing impurities such as $\mathrm{NO}_{2}$ and $\mathrm{H}_{2} \mathrm{O}_{2}$ formed by radiolysis of $\mathrm{N}_{2}$ and $\mathrm{H}_{2} \mathrm{O}$ or residual $\mathrm{O}_{2}$ in a nitrogen cover gas system are reactive with $\mathrm{UO}_{2}$. The extent of the degradation that could be caused by these impurities depends on their concentrations, the kinetics of the reactions, and the temperature-time exposure. The potential for moist nitrogen to oxidize $\mathrm{UO}_{2}$ was shown to be limited to a stoichiometry corresponding to an $0 / \mathrm{U}$ ratio not greater than $\mathrm{U}_{2,006}$ *

The kinetics of the reactions were not considered. Because of the 20- to 40-year interim storage periods under consideration, it was conservatively assumed that all thermodynamically favorable reactions will proceed to completion. The reactivity of the very large Zircaloy fuel cladding surface area with these impurities and the potentially small inventory of radiolysis products in a dry storage system limits the amount of fuel that could be oxidized at cladding breach sites to a negligibly small amount.

Tests involving both nonirradiated $\mathrm{UO}_{2}$ pellets at $225^{\circ} \mathrm{C}, 250^{\circ} \mathrm{C}$, and $275^{\circ} \mathrm{C}$ and spent $\mathrm{UO}_{2}$ fuel fragments at $275^{\circ} \mathrm{C}$ and $380^{\circ} \mathrm{C}$ were conducted at Pacific 
Northwest Laboratory. An external gamma radiation field was imposed on the test atmosphere and specimens to provide radiolysis. After 7 weeks of testing, there were negligible weight gains and no change in the physical appearance of the specimens. The low reactivity of the nitrogen atmosphere for the duration of the test was evident by comparison with test results in air under comparable conditions. Tests in air for less than 1 week resulted in significant weight gains and powder generation by formation of low-density oxides of uranium.

Thus, it has been shown that no significant degradation occurred to $\mathrm{UO}_{2}$ fuel in nitrogen within 7 weeks at temperatures up to $380^{\circ} \mathrm{C}$. If reactions between the $\mathrm{UO}_{2}$ fuel and the limited reactants available in the nitrogen storage atmosphere are assumed to go to completion during 20 to 40 years of dry storage, no deleterious degradation of the $\mathrm{UO}_{2}$ fuel would be expected. This conclusion assumes that acceptable cask leak rates do not significantly increase. No credit was taken for the large surface area of Zircaloy cladding that provides an alternate sink for gaseous reactants. 


\section{CONTENTS}

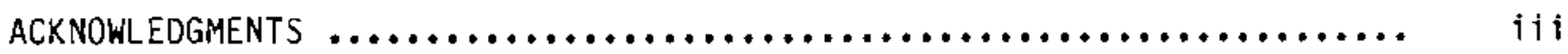

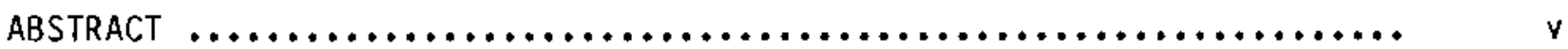

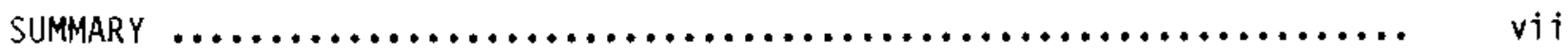

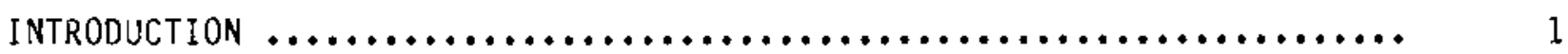

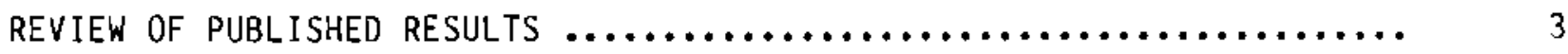

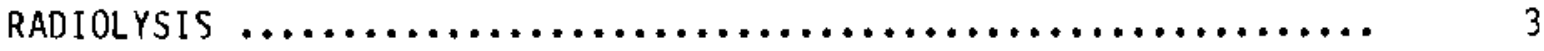

TESTS WITH SPENT FUEL AT FRG OBRIGHEIM $\ldots \ldots \ldots \ldots \ldots \ldots \ldots \ldots \ldots \ldots \ldots \ldots \ldots$

TESTS WITH SPENT FUEL AT BATTELLE COLUMBUS LABORATORIES $\ldots \ldots \ldots \ldots .5$

TESTS WITH SPENT FUEL AT NTS-EMAD $\ldots \ldots \ldots \ldots \ldots \ldots \ldots \ldots \ldots \ldots \ldots \ldots \ldots \ldots$

TESTS WITH SPENT FUEL AT GE MORRIS $\ldots \ldots \ldots \ldots \ldots \ldots \ldots \ldots \ldots \ldots \ldots \ldots \ldots$

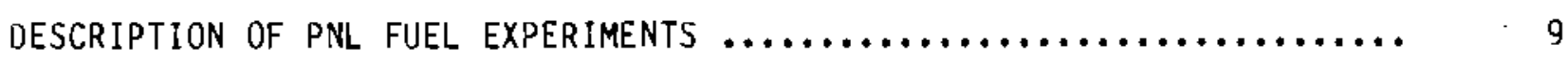

PRELIMINARY TESTING IN AIR-1 vol\% $\mathrm{NO}_{2} \ldots \ldots \ldots \ldots \ldots \ldots \ldots \ldots \ldots \ldots \ldots \ldots$

PRELIMINARY TESTING WITH A GaMMA FIELD IN AIR $\ldots \ldots \ldots \ldots \ldots \ldots \ldots . . . \ldots$

nonirradiated bare $U_{2}$ Pellet tests in nitrogen $\ldots \ldots \ldots \ldots \ldots \ldots \ldots, 12$

BARE SPENT FUEL FRAGMENT TESTS IN NITROGEN $\ldots \ldots \ldots \ldots \ldots \ldots \ldots \ldots .14$

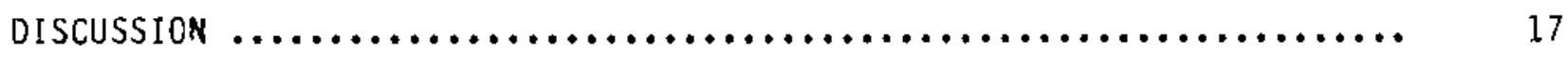

THERMODYNAMICS OF URANIUM-OXYGEN COMPOUNDS $\ldots \ldots \ldots \ldots \ldots \ldots \ldots \ldots . . .17$

THERMODYNAMICS OF REACTIONS BETWEEN URANIUM OXIDE AND WATER $\ldots \ldots .18$

THERMODYNAMICS OF REACTIONS BETWEEN OXIDES OF URANIUM AND $\mathrm{N}_{\mathrm{x}} \mathrm{O}_{\mathrm{y}} \cdots \quad 18$

THERMODYNAMICS OF REACTIONS BETWEEN ZIRCONIUM AND NITROGEN

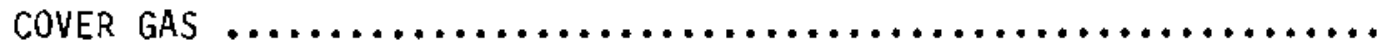

APPLICATION OF RESULTS TO INTERIM DRY STORAGE OF SPENT FUEL

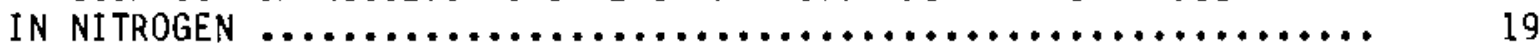

CONCLUSIONS $\ldots \ldots \ldots \ldots \ldots \ldots \ldots \ldots \ldots \ldots \ldots \ldots \ldots \ldots \ldots \ldots \ldots \ldots \ldots \ldots,{ }_{23}$

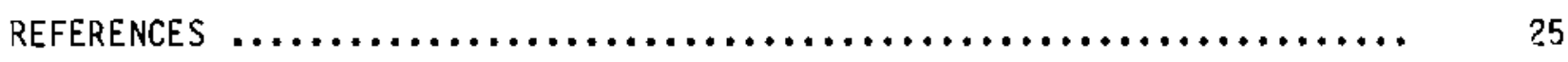


APPENDIX A - THERMODYNAMICS OF CHEMICAL REACTIONS OF OXIDES OF URANIUM WITH OXYGEN AT $200^{\circ} \mathrm{C} \ldots \ldots \ldots \ldots \ldots \ldots \ldots \ldots \ldots \ldots \ldots \ldots$ A.1

APPENDIX B - CONCENTRATIONS OF FISSION PRODUCTS FROM 35,000 MWd/MTU PWR FUEL AT OISCHARGE AND 10 YEARS

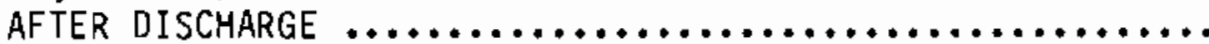

APPENDIX C - THERMODYNAMICS OF CHEMICAL REACTIONS BETWEEN OXIDES

OF URANIUM AND $\mathrm{H}_{2} \mathrm{O}, \mathrm{CO}$, AND $\mathrm{CO}_{2}$ AT $200^{\circ} \mathrm{C} \ldots \ldots \ldots \ldots \ldots . . . . .1$

APPENDIX 0 - THERMODYNAMICS OF CHEMICAL REACTIONS BETWEEN OXIDES

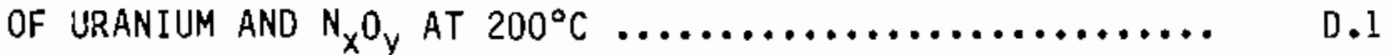

APPENOIX E - THERMOOYNAMICS OF CHEMICAL REACTIONS BETWEEN $\mathrm{H}_{2} \mathrm{O}_{2}$

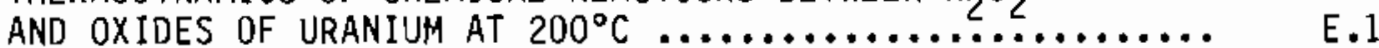

APPENDIX $\mathrm{F}$ - THERMOOYNAMICS OF REACTIONS OF ZIRCONIUM WITH $\mathrm{O}_{2}, \mathrm{H}_{2} \mathrm{O}_{2}$, $\mathrm{H}_{2} \mathrm{O}, \mathrm{N}_{2}, \mathrm{~N}_{2} \mathrm{O}$, AND $\mathrm{NO}_{2}$ AT $200^{\circ} \mathrm{C} \ldots \ldots \ldots \ldots \ldots \ldots \ldots \ldots \ldots, \mathrm{F} .1$ 


\section{FIGURES}

$1 \mathrm{NO}_{2}$ and $\mathrm{HNO}_{3}$ Concentrations as a Function of Dose $\ldots \ldots \ldots \ldots \ldots$

2 Typical Cask Used for the BWR Cask Characterization Test ........ 7

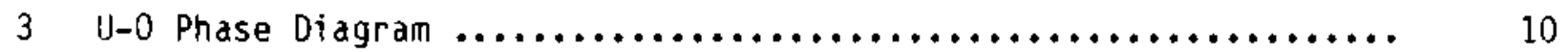

4 Oxidation of Nonirradiated $\mathrm{UO}_{2}$ Pellets in Air and $\mathrm{Ai}-1$ vol\%

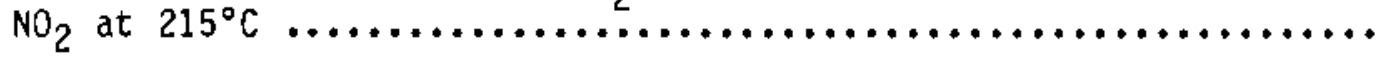

5 Oxidation of Nonirradiated $\mathrm{NO}_{2}$ Pellets in Air and Air-1 vol\%

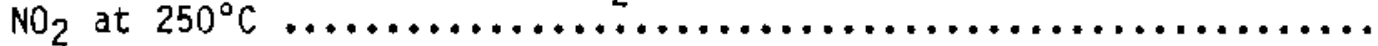

6 Effect of Gamma Radiation on Oxidation of Nonirradiated $\mathrm{UO}_{2}$

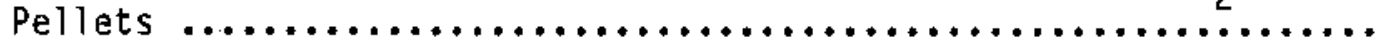




\section{TABLES}

1 Radicals and Compounds Formed by Radiolysis of Moist Nitrogen $\ldots \ldots \ldots \ldots \ldots \ldots \ldots \ldots \ldots \ldots \ldots \ldots \ldots \ldots \ldots \ldots \ldots \ldots \ldots \ldots \ldots$

2 Results of Tests on Nonirradiated $\mathrm{UO}_{2}$ Pellets in Moist Nitrogen in a Gamma Field of $200,000^{2} / h \ldots \ldots \ldots \ldots \ldots \ldots \ldots . . . \ldots$

3 Results of Tests with Spent LWR Fuel in $275^{\circ} \mathrm{C}$ Moist Nitrogen Cover Gas .........................................

4 Results of Tests with Spent LWR Fuel in $380^{\circ} \mathrm{C}$ Moist Nitrogen

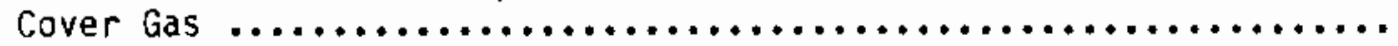




\section{INTROOUCTION}

Nitrogen is being considered as an atmosphere and heat transfer medium for interim dry storage of spent nuclear fuel. Nitrogen has been used internationally as an atmosphere for dry shipments of spent fuel. It is less prone to leakage than helium; and it is less reactive with spent fuel than air, which can oxidize fuel exposed at cladding defects at sufficiently high temperatures. Based on results of dry storage tests and demonstrations in air with spent Tight-water reactor (LWR) fuel (White et a1. 1983; Einziger and Cook 1983; Johnson et al. 1983b; Einziger and Strain 1985; Johnson et al. 1985), storage temperatures that exceed yet-to-be-determined limits will require an inert cover gas to prevent potential cladding degradation by fuel oxidation in fuel rods with cladding breaches.

Evaluations sponsored by the U.S. Department of Energy (DOE) Comfnercial Spent Fuel Management (CSFM) Program at Pacific Northwest Laboratory (PNL) (a) have led to a less-restrictive but still-conservative temperature guideline that would allow fuel temperatures as high as $380^{\circ} \mathrm{C}$ during dry storage of spent fuel in inert cover gases in the United States (Johnson and Gilbert 1983b; Gilbert, Johnson, and Bailey 1985). The selection of this limit was based on results of dry storage tests and demonstrations in the Federal Republic of Germany (FRG) (Kaspar et al. 1982; Fleisch, Einfeld, and Luhrmann 1982) and conservative criteria for prevention of cladding breaches during dry storage by creep rupture (Chin and Madsen 1983).

Inert cover gases that have been used in dry storage tests and denonstrations include argon, helium, and neon (Johnson and Gilbert 1983b). Although nitrogen is not an inert gas, it is a potential atmosphere for spent fuel storage. Nitrogen has a lower thermal conductivity than helium; its higher density enables higher heat transfer by convection than in helium under thermal gradients in spent fuel dry storage systems; and it is relatively inexpensive. Because of its larger mass, nitrogen is less susceptible to leakage through small orifices by knudsen flow than lower mass atoms of helium or neon (Dushman

(a) Operated for DOE by Battelle Memorial Institute under Contract DE-ACD6-76RLO 1830 . 
and Lafferty 1962). The specific benefits of using nitrogen instead of helium will depend on a number of design and operational considerations that require specific evaluation. The objective of the work reported this document is to provide a technical evaluation of the suitability of nitrogen as an interim dry storage atmosphere from the perspective of compatibility with spent Zircaloy fuel cladding, exposed $\mathrm{VO}_{2}$ at cladding breach sites, and storage system components.

Although nitrogen reacts with metallic uranium to form uranium-nitrogen compounds, it is not thermodynamically favorable for nitrogen to reduce uranium oxides.

This report assesses data on the thermodynamics of zirconium and uranium oxide reactions with nitrogen and spent fuel cover gas impurities (moisture and radiolysis products), reviews experience with storing spent LWR fuel in nitrogen, and presents results of tests performed at PNL with $\mathrm{UO}_{2}$ pellets and spent LWR fuel fragments in moist nitrogen. The PNL tests were designed to determine the compatibility of nonirradiated $\mathrm{UO}_{2}$ pellets with moist nitrogen in a $200,000-R / h$ gamma irradiation field at $225^{\circ} \mathrm{C}, 250^{\circ} \mathrm{C}$, and $275^{\circ} \mathrm{C}$. Parallel tests were conducted on irradiated LWR fuel in moist nitrogen at $275^{\circ} \mathrm{C}$ and $380^{\circ} \mathrm{C}$. The results from these tests are presented in this report. These tests were performed to support the use of nitrogen as an atmosphere in the Cask Characterization Test with spent boiling water reactor (BWR) fuel at the General Electric (GE) Morris fuel storage facility in Illinois (Newman 1985) and other cooperative DOE/utility dry storage demonstrations (Daily 1984). A broader consideration was to provide supporting data for qualifying nitrogen as a cover gas for licensed dry storage of spent fuel in the United States. 
REVIEW OF PUBLISHED RESULTS

The results of tests conducted with spent fuel in the FRG, at Battelle Columbus Laboratories (BCL), at the Nevada Test Site (NTS), and at GE Morris are summarized in this section.

\section{RADIOLYSIS}

Some oxides of nitrogen are reactive with the oxides of uranium. Although oxides of nitrogen are not expected to occur naturally in significant quantities in nitrogen, they are formed by radiolysis of nitrogen and oxygen in a radiation field. Some $\mathrm{N}_{x} \mathrm{O}_{y}$ compounds, such as $\mathrm{N}_{2}$, are strong oxidants and enhance oxidation rates in both reactive metals and ceramics (Samsonov 1973). Several of these compounds have negative free energies of reaction with $\mathrm{UO}_{2}$ (Appendix D) and will oxidize $\mathrm{UO}_{2}$ if the kinetics are sufficiently rapid. Radiolysis of nitrogen in the presence of oxygen or moisture in a radiation field generates $\mathrm{N}_{x} \mathrm{O}_{y}$ compounds (Denaro and Jayson 1972). Radicals and products of radiolysis of nitrogen and moisture are shown in Table 1. Experimental results showing the effects of irradiation on the generation of $\mathrm{NO}_{2}$ and $\mathrm{HNO}_{3}$ in dry and moist nitrogen gases at $12 D^{\circ} \mathrm{C}$ are shown in Figure 1 (Tokunaga et al. 1978).

\section{TESTS WITH SPENT FUEL AT FRG OBRIGHEIM}

Results from tests performed by the FRG in moist nitrogen at the Obrigheim reactor have been reported for spent PWR fuel assemblies with fuel rods having burnup levels of 33,000 to 43,700 MWd/MTU (Peehs, Kuhnel, and Kaspar 1982;

TABLE 1. Radicals and Compounds Formed by Radiolys is of Moist Nitrogen

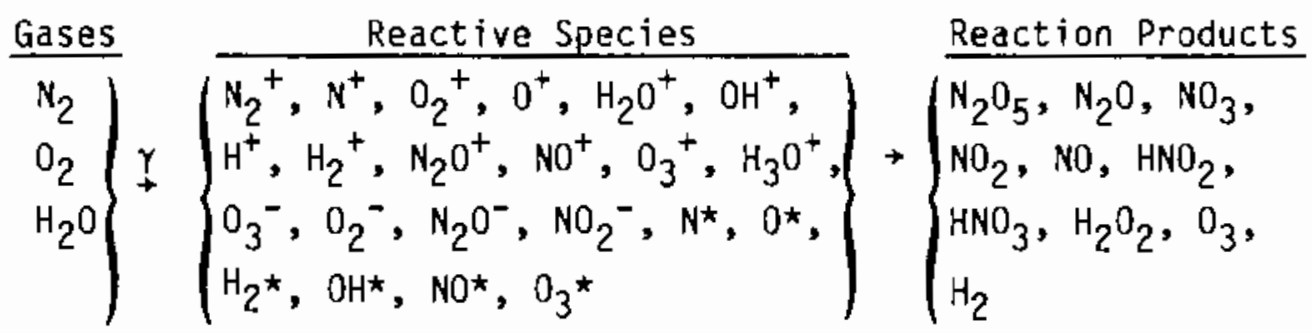



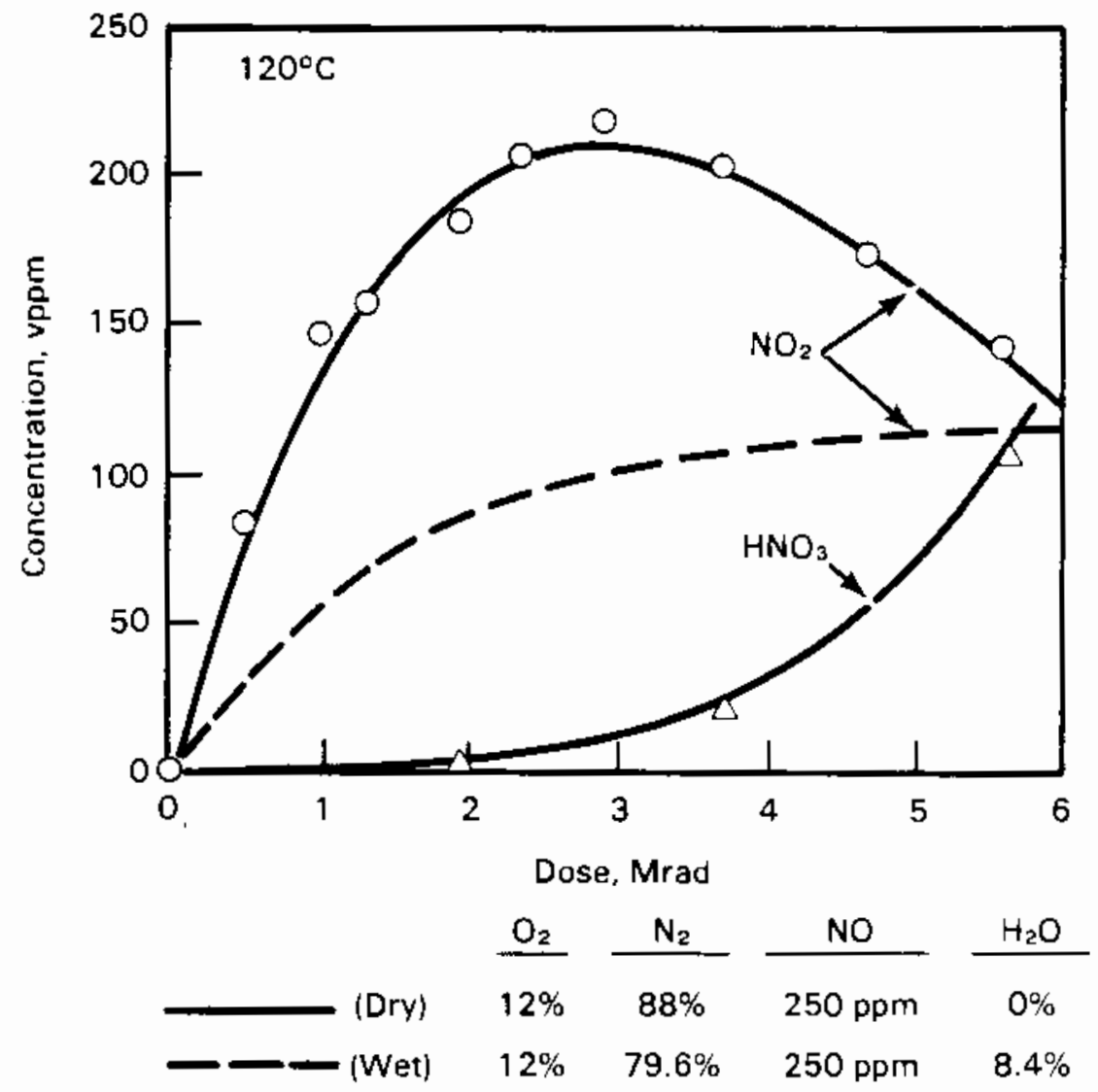

FIGURE 1. $\mathrm{NO}_{2}$ and $\mathrm{HNO}_{3}$ Concentrations as a Function of Dose (1 $\operatorname{Mrad}=50$ days at $10^{5} \mathrm{R} / \mathrm{h}$ ) (Tokunaga et al. 1978)

Kaspar et a 1. 1982). The tests were conducted in a nitrogen-filled chamber immersed in and exposed to pool water for up to 60 days with a starting fuel temperature of $300^{\circ} \mathrm{C}$ and for up to 1 year with a starting fuel temperature of $400^{\circ} \mathrm{C}$. No fuel assembly degradation was found during post-test visual examination. However, there were no known breached fuel rods in the test. Both fission gas analysis of the nitrogen atmosphere and sipping of the fuel rods were used to verify the absence of failed fuel.

Because the $\mathrm{UO}_{2}$ fuel was protected by the Zircaloy-4 cladding, this test cannot be used to confirm the compatibility of spent $\mathrm{UO}_{2}$ fuel with moist nitrogen (White et al. 1983; Johnson et al. 1983a; Kaspar et al. 1982; Peehs, Kuhnel, and Kaspar 1982). However, the Obrigheim test does indicate that there is no severe reaction between the $\mathrm{ZrO}_{2}$-coated $\mathrm{Zircaloy}$ cladding and the moist nitrogen and is consistent with the low rates of reaction of Zircaloy with 
oxygen and nitrogen at $325^{\circ} \mathrm{C}$ (Johnson and Gilbert 1983a). However, a quantitative post-test examination of the zircaloy cladding was not reported.

\section{IESTS WITH SPENT FUEL AT BATTELLE COLUMBUS LABORATORIES}

The tendency for reactor-breached spent fuel rods to contain moisture was the basis for an ultrasonic method used to identify breached fuel rods (Cruickshank 1985; Boehm and Foerch 1985). In one series of spent fuel examinations, 47 fuel rods from 36 fuel assemblies were found to contain moisture (walton et al. 1985). To determine the behavior of water-logged spent fuel in dry storage, in-air tests on breached BWR spent fuel rods were sponsored by the DOE CSFM Program and conducted by $8 \mathrm{CL}$. The results from these tests provide supporting information on the compatibility between $\mathrm{UO}_{2}$ or Zircaloy cladding and nitrogen (Johnson et a1. 1983b; Kohli et a1. 1985).

The tests were continued for $2100 \mathrm{~h}$ at $325^{\circ} \mathrm{C}$. The oxygen in the air cover gas was depleted within approximately $10 \mathrm{~h}$ by oxidation of the spent fuel through reactor-induced cladding breaches. The residual nitrogen was repeatedly evacuated and replaced with air. During the $10-h$ period while the oxygen was being depleted, the pressure decreased by approximately $20 \%$ and then became stable. During this stable pressure period, the cover gas was composed primarily of nitrogen. If the spent fuel or the Zircaloy cladding were reacting with the nitrogen atmosphere, a corresponding pressure reduction would be expected. The only pressure change that was measured following depletion of the oxygen was a slow increase during the first few hundred hours of the test. This slow pressure increase was attributed to approximately $4 \mathrm{~g}$ of bound moisture that was slowly released from the water-logged fuel and not to any reaction between the nitrogen atmosphere and the spent fuel that would have caused a pressure reduction. After a few hundred hours, the moisture release was too slow to generate a measurable pressure increase.

The reactor-breached spent fuel test in air and a parallel test in argon showed that up to $10 \mathrm{~g}$ of moisture per rod was released (Johnson et a1. 1983a; Kohli et al. 1985). Over half of this moisture was released very rapidly under vacuum and therefore would have been released during vacuum drying operations in a storage cask. A small amount of moisture (up to $4 \mathrm{~g}$ per rod) appeared to 
be bound in the fuel and was slowly released (Kohli et al. 1985). Other studies indicate that some moisture may be bound in the fuel. (a)

\section{TESTS WITH SPENT FUEL AT NTS-EMAD}

Significant amounts of $\mathrm{N}_{2} \mathrm{O}$ (up to $2500 \mathrm{vppm}$ ) were found in samples of the air atmosphere surrounding a single PWR spent fuel assembly in the Fuel Temperature Test (FTT) initiated at $275^{\circ} \mathrm{C}$ at the Engine Maintenance and Disassembly Facility (EMAD) at NTS (Johnson et al. 1985). The $\mathrm{N}_{2} \mathrm{O}$ buildup was attributed to radiolysis of nitrogen and oxygen by gamma irradiation of the air atmosphere surrounding the spent fuel assembly and subsequent reactions between nitrogen and oxygen. Post-test visual examination and swipe tests for smearable fuel contamination of the fuel assembly revealed no evidence for reaction between the atmosphere and the Zircaloy cladding or the fuel at an unidentified cladding breach that formed within the first 2 months of the 2-year test.

\section{TESTS WITH SPENT FUEL AT GE MORRIS}

A BWR Cask Characterization Test was performed at the away-from-reactor spent fuel storage pool at GE Morris in Illinois (Newman 1985). The primary objective of the test was to verify heat transfer and radiation shielding code predictions and cask performance. Nitrogen was used as the atmosphere for one series of tests with up to 52 BWR spent fuel assemblies enclosed in the cask. A sketch of a typical dry storage cask is shown in Figure 2; the cask is approximately $4.9 \mathrm{~m}$ high with an internal cavity diameter of about $155 \mathrm{~cm}$. If all of the pressure associated with cask evacuation to 1 torr prior to filling the cask with nitrogen were due to moisture, the dew point would be approximately $-20^{\circ} \mathrm{C}\left(4 \mathrm{~g}\right.$ of moisture in the $5.4 \times 10^{6} \mathrm{~cm}^{3}$ cask atmosphere). Analyses of gas samples taken from the cask atmosphere indicated a total moisture content of 0.6 to $2.7 \mathrm{~g}$. Post-test visual examination and pre- and post-test wet sipping of the fuel showed no detectable degradation to the spent fuel as semblies.

(a) 01 ander, Sherman, and Balooch 1982; Beyer and Hann 1977; Spalaris and Magerth 1963; Denovan, Ashley, and Longhurst 1971; Ferrari 1963. 

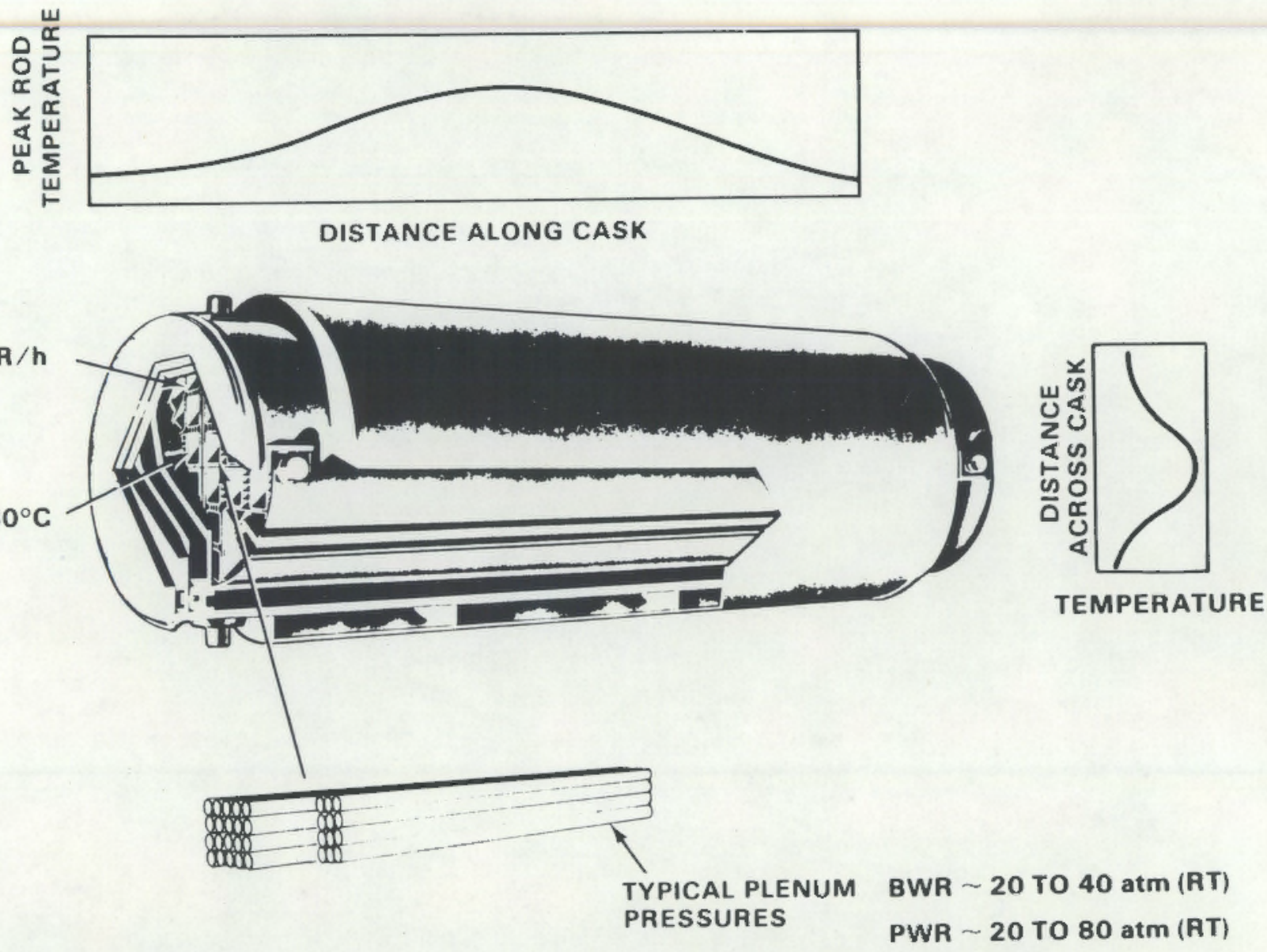

FIGURE 2. Typical Cask Used for the BWR Cask Characterization Test 


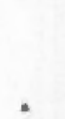

.

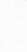




\section{DESCRIPTION OF PNL FUEL EXPERIMENTS}

DOE/CSFM-sponsored tests were conducted on both nonirradiated and irradiated $\mathrm{UO}_{2}$ to determine if the radiolysis products of moist nitrogen would oxidize $\mathrm{UO}_{2}$. The experimental procedures for $\mathrm{UO}_{2}$ pellet and spent fuel tests at PNL have been published (White et al. 1983; Knox, Gilbert, and White 1985). Bare fuel pellets (approximately $5.5 \mathrm{~g}$ each) or bare spent fuel fragments ( 3 to $5 \mathrm{~mm}$ edge lengths) were placed in ovens with a controlled atmosphere of: 1) air-1 vol\% $\mathrm{NO}_{2}, 2$ ) moist air or moist nitrogen in a gamma field generated by a cobalt-60 source, or 3) moist nitrogen in a gamma field generated by $\mathrm{CsCl}$ capsules. The air-1 vol\% $\mathrm{NO}_{2}$ mixture was used to synthesize a radiolysis product, while gamma radiation was used to simulate radiolytic effects of the gamma field generated by spent fuel in a dry storage installation. Gas samples taken from the test atmospheres were analyzed before and after the test. The tests were periodically interrupted for weighing and visual examination of specimens.

The objectives of the tests performed in air were to determine if the presence of a synthesized radiolysis product would affect the oxidation of $\mathrm{UO}_{2}$ and to determine if radiolysis of air would affect the oxidation of $\mathrm{UO}_{2}$. The fuel gained weight with increasing time at temperature due to the oxidation. Oxides of uranium between $\mathrm{UO}_{2}$ and $\mathrm{UO}_{3}$ are shown in the phase diagram in Figure 3 .

\section{PRELIMINARY TESTING IN AIR-1 v01\% $\mathrm{NO}_{2}$}

Tests simulating the effect of radiolysis products on oxidation of $\mathrm{UO}_{2}$ in air were performed at PNL by using air containing 1 vol\% $\mathrm{NO}_{2}$. The rate of weight gain in low-density nonirradiated $U 0$ pellets (Figures 4 and 5) (White et al. 1983) was significantly higher than in air. The significantly larger weight gains for one of the pellet tests described in Figure 4 for air-1 vol\% $\mathrm{NO}_{2}$ was attributed to its low theoretical density of $95 \%$. The other pellets tested in air-1 vol\% $\mathrm{NO}_{2}$ and air had approximately $96 \%$ theoretical density. 


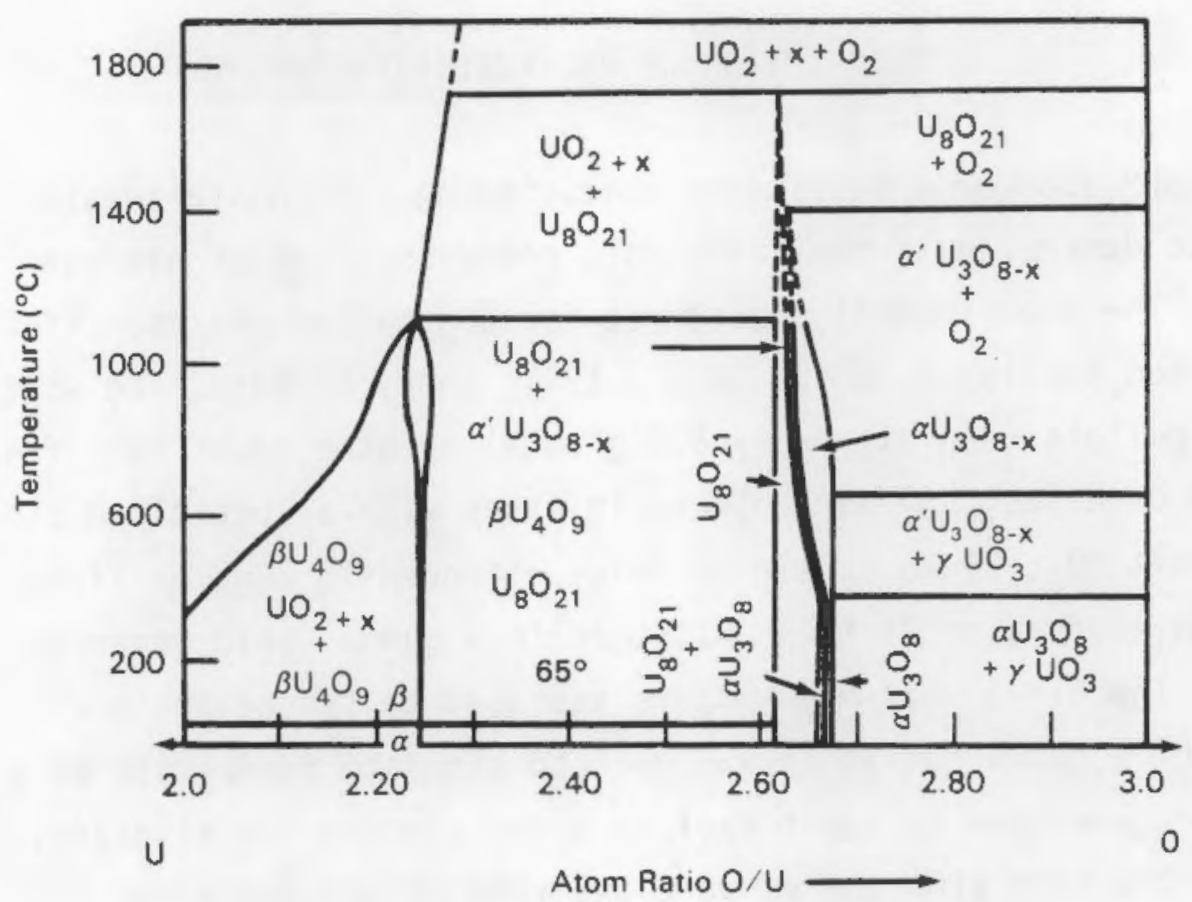

FIGURE 3. U-0 Phase Diagram (Roth et al. 1981)

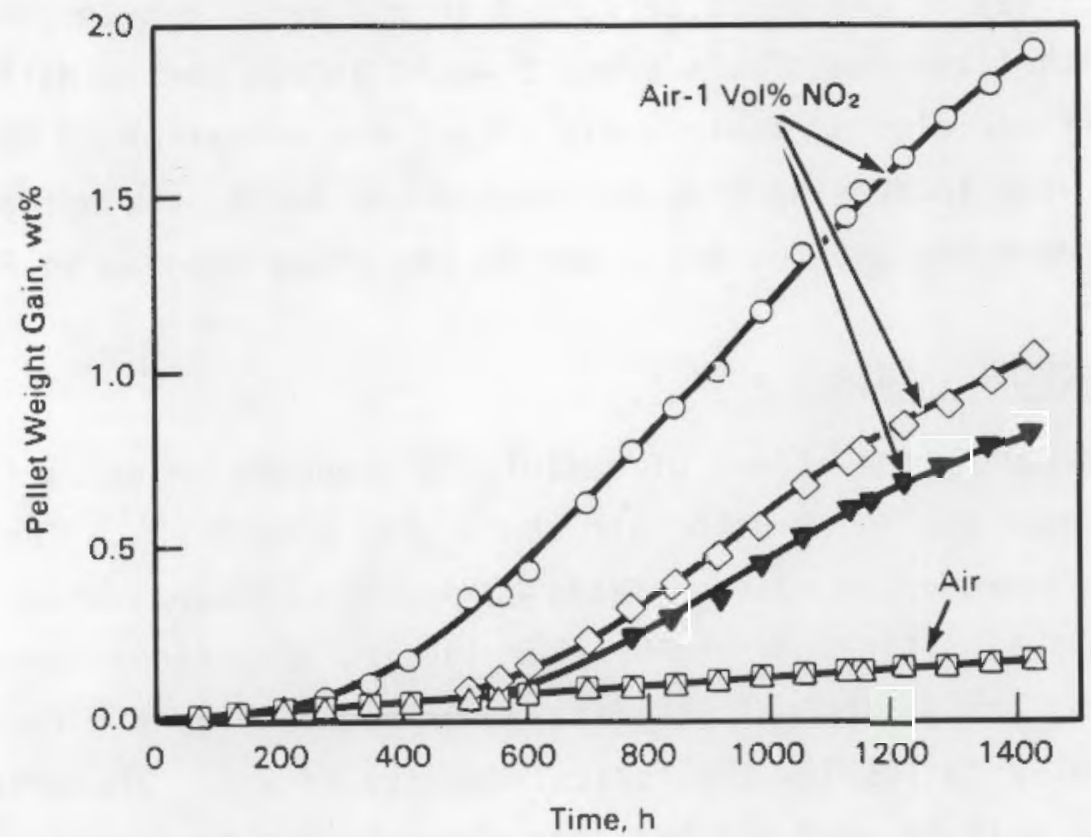

FIGURE 4. Oxidation of Nonirradiated $\mathrm{UO}_{2}$ Pellets in Air and Air-1 vol\% $\mathrm{NO}_{2}$ at $215^{\circ} \mathrm{C}$. The large weight increases for the highest curve are attributed to its low density of only $95 \%$ theoretical compared with the approximately $96 \%$ theoretical for the other pellets. 


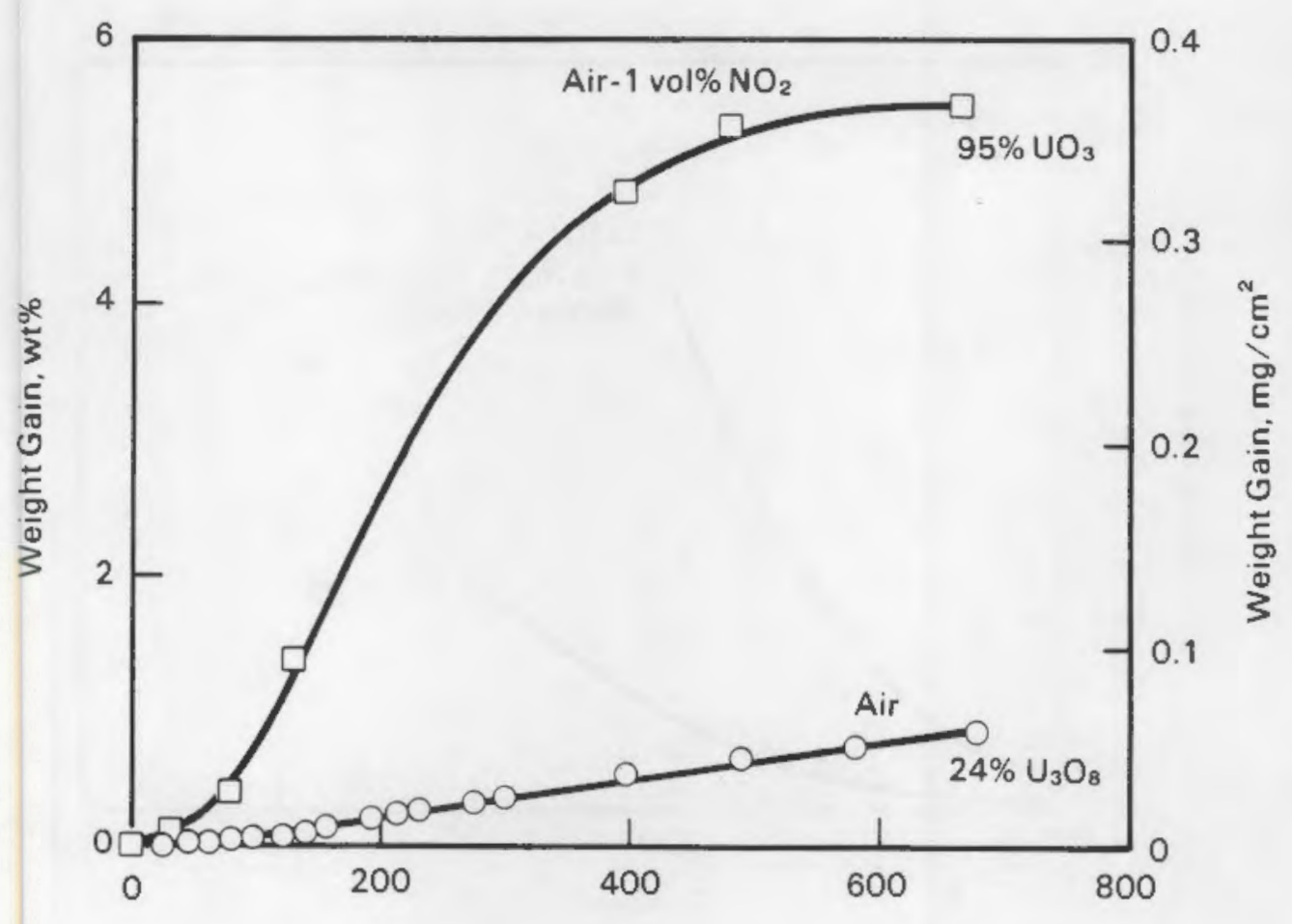

Time, $\mathrm{h}$

FIGURE 5. Oxidation of Nonirradiated $\mathrm{UO}_{2}$ Pellets in Air and $\mathrm{Air}-1$ vol\% $\mathrm{NO}_{2}$ at $250^{\circ} \mathrm{C}$

PRELIMINARY TESTING WITH A GAMMA FIELD IN AIR

Tests were performed at PNL to explore the effects of a gamma field in producing reactive radiolysis products and the subsequent effects on $\mathrm{UO}_{2}$ oxidation. These tests, conducted in a $200,000 \mathrm{R} / \mathrm{h}$ gamma field generated by a cobalt-60 source, resulted in accelerated oxidation of nonirradiated $\mathrm{UO}_{2}$ pellets (Figure 6 ). The final product was $\mathrm{UO}_{3}$ powder. Although no $\mathrm{N}_{2} \mathrm{O}$ was found in chemical analyses of test atmosphere gas samples at the completion of the test, the concentration of $\mathrm{N}_{2} \mathrm{O}$ in the test chamber was slightly greater than $100 \mathrm{vppm}$ after less than 1 week of irradiation. These tests demonstrated that radiolysis products form in a gamma field of intensity typical of that expected in a dry storage installation containing spent LWR fuel and that $\mathrm{UO}_{2}$ pellet oxidation was accelerated in a gamma field typical of a dry storage installation. 


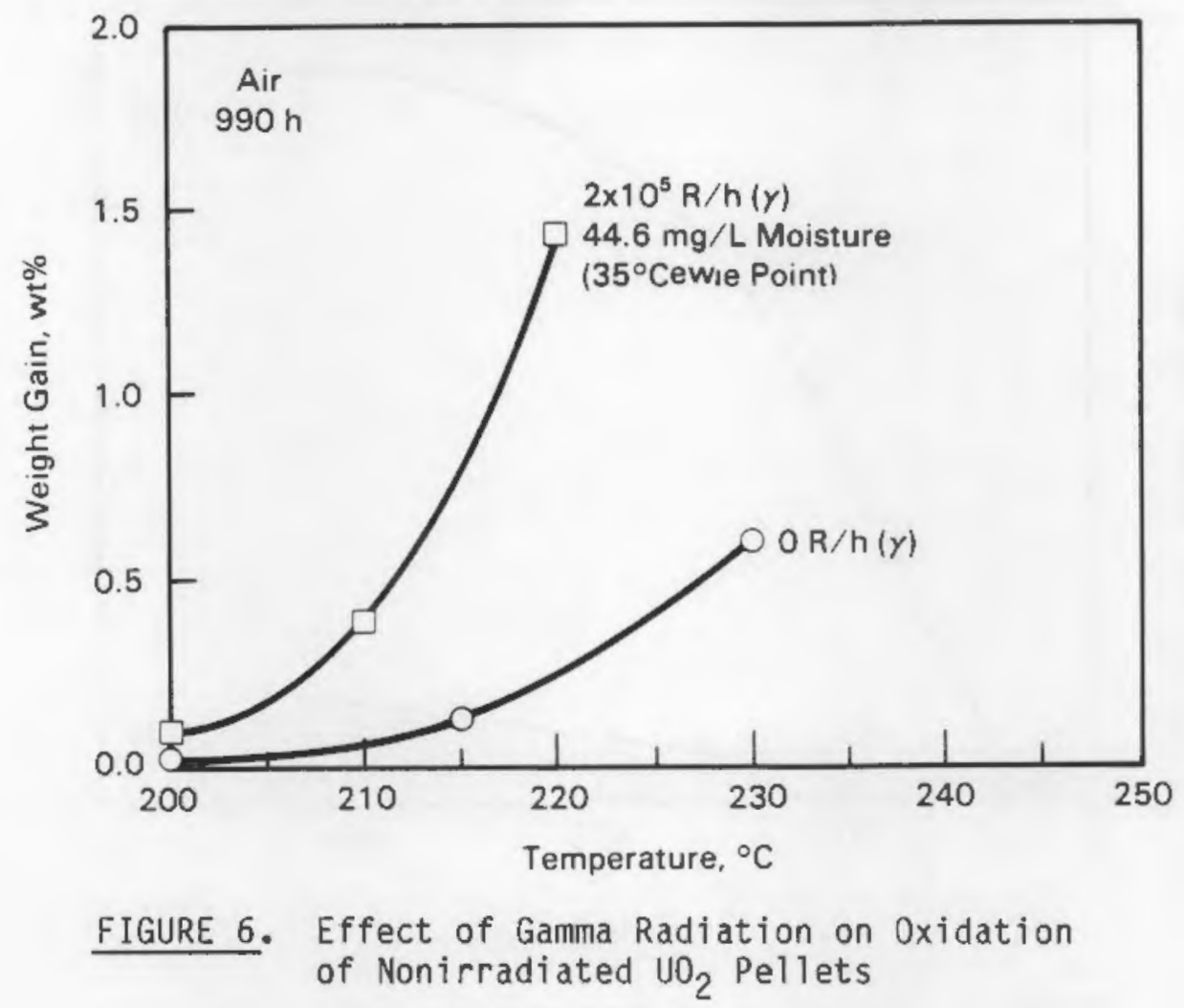

NONIRRADIATED BARE $U_{2}$ PELLET TESTS IN NITROGEN

A nonirradiated $\mathrm{UO}_{2}$ pellet was placed in each of three gas-tight capsules that were evacuated and backfilled with nitrogen at a $20^{\circ} \mathrm{C}$ dew point. The three cells were maintained at $225^{\circ} \mathrm{C}, 250^{\circ} \mathrm{C}$, and $275^{\circ} \mathrm{C}$, respectively, in a gamma field of $200,000 \mathrm{R} / \mathrm{h}$. Pellet densities were $96.4 \%, 95.1 \%$, and $95.7 \%$ of theoretical, respectively, at each temperature. The oxygen concentration measured in pre- and post-test samples of the atmosphere was less than 0.01 vol\%. The gamma field intensity is typical of the gamma field generated by a 35,000 MWd/MTU spent PWR fuel assembly approximately 7 years after reactor discharge or a 20,000 MWd/MTU spent BWR fuel assembly approximately 3 years after reactor discharge (Croff 1980). The pellet appearance was observed, and the weight change was determined after 455 and 1165 cumulative hours at the test temperature. As shown in Table 2, there were no measurable weight changes. The reduced nitrogen concentration shown in the gas analyses in Table 2 is associated with the formation of $\mathrm{CO}_{2}$. The pellets retained a glossy surface 
TABLE 2. Results of Tests on Nonirradiated $\mathrm{UO}_{2}$ Pellets in Moist Nitrogen in a Gamma Field of $200,000^{2} \mathrm{R} / \mathrm{h}$

\begin{tabular}{|c|c|c|c|c|c|c|}
\hline Temperature, ${ }^{\circ} \mathrm{C}$ & Time, $h$ & Weight, $\mathrm{g}$ & $\begin{array}{l}\text { Weight } \\
\text { Change, g }\end{array}$ & $\mathrm{CO}_{2}, \mathrm{vol \%}$ & $\mathrm{H}_{2}$, vol\% & $\mathrm{N}_{2}$, vol\% \\
\hline $\begin{array}{l}225 \\
250 \\
275\end{array}$ & $\begin{array}{l}0 \\
0 \\
0\end{array}$ & $\begin{array}{l}5.4432 \\
5.3199 \\
5.2688\end{array}$ & $\begin{array}{l}-- \\
-- \\
--\end{array}$ & $\begin{array}{l}<0.01 \\
<0.01 \\
<0.01\end{array}$ & $\begin{array}{l}<0.01 \\
<0.01 \\
<0.01\end{array}$ & $\begin{array}{l}99.9 \\
99.9 \\
99.9\end{array}$ \\
\hline $\begin{array}{l}225 \\
250 \\
275\end{array}$ & $\begin{array}{l}445 \\
445 \\
295\end{array}$ & $\begin{array}{l}5.4431 \\
5.3197 \\
5.2687\end{array}$ & $\begin{array}{l}-0.0001 \\
-0.0002 \\
-0.0001\end{array}$ & $\begin{array}{l}0.28 \\
0.63 \\
0.51\end{array}$ & $\begin{array}{l}0.1 \\
<0.01 \\
<0.01\end{array}$ & $\begin{array}{l}99.6 \\
99.4 \\
99.5\end{array}$ \\
\hline $\begin{array}{l}225 \\
250 \\
275\end{array}$ & $\begin{array}{l}1165 \\
1165 \\
1015\end{array}$ & $\begin{array}{l}5.4430 \\
5.3196 \\
5.2689\end{array}$ & $\begin{array}{r}-0.0002 \\
-0.0003 \\
0.0001\end{array}$ & $\begin{array}{l}0.18 \\
0.46 \\
0.3\end{array}$ & $\begin{array}{l}0.08 \\
0.02 \\
0.06\end{array}$ & $\begin{array}{l}99.74 \\
99.43 \\
99.64\end{array}$ \\
\hline
\end{tabular}

with no evidence of cracking or degradation. The specimens and reaction products were analyzed by $x$-ray diffraction to determine if changes in composition and crystal form had resulted from exposure to the moist nitrogen cover gas; no changes were found.

The gas volume of each test cell was $163 \mathrm{~cm}^{3}$. The nitrogen cover gas was introduced into the cell at a dew point of $20^{\circ} \mathrm{C}$ or a moisture content of $0.017 \mathrm{mg} / \mathrm{cm}^{3}$, which corresponds to $2.8 \mathrm{mg}$ of moisture in each test cell. The amount of oxygen combined in $2.8 \mathrm{mg}$ moisture is approximately $2.5 \mathrm{mg}$. Based on the changes in pellet weights shown in Table 2, no measurable oxidation occurred. Most pellet tests in air showed visibie $\mathrm{U}_{3} \mathrm{O}_{8}$ formation at a weight increase of 2 to $8 \mathrm{mg}$ per $\mathrm{UO}_{2}$ pellet. Therefore, it is possible that if all of the oxygen reacted with the fuel pellet $\mathrm{U}_{3} \mathrm{O}_{8}$ formation might have been observed. However, based on the lack of weight increase, it appears that there was no significant oxidation. It can be concluded that either the radiolysis was inadequate to produce oxygen for reaction with the $\mathrm{UO}_{2}$ or the oxygen was not available for reaction.

Ouring preliminary tests for verification of procedures and equipment integrity, oxygen inleakage caused $\mathrm{U}_{3} \mathrm{O}_{8}$ powder to form within 1 week after initiation of a test at $275^{\circ} \mathrm{C}$. In subsequent tests after the leaks were eliminated and only moist nitrogen was introduced, no weight gain was found and no 
powder formed. From the contrast in pellet behavior in air and in nitrogen, it was apparent that the nitrogen cover gas did not result in significant pellet degradation.

\section{BARE SPENT FUEL FRAGMENT TESTS IN NITROGEN}

Tests on bare spent fuel fragments were conducted at $275^{\circ} \mathrm{C}$ with fuel from Point Beach $(29,000$ MWd/MTU peak burnup), H. B. Robinson (33,000 MWd/MTU peak burnup), and Shippingport (34,000 MWd/MTU peak burnup; 24,000 MWd/MTU average burnup) reactors in moist $\left(20^{\circ} \mathrm{C}\right.$ dew point) nitrogen. Tests were a1so conducted at $380^{\circ} \mathrm{C}$ with six spent fuel samples at a dew point of $30^{\circ} \mathrm{C}$. Since the dew point in a dry storage atmosphere is expected to be on the order of -40 to $-20^{\circ} \mathrm{C}$, these tests were performed at a higher moisture level than spent fuel will be subjected to in storage. The formation of radiolytic products increases with moisture content (Figure 1). Therefore, the atmospheres in these tests should be more reactive than those formed in a dry storage installation. The pre- and post-test specimen weights and results of gas analyses are shown in Tables 3 and 4.

A cesium chloride gamma irradiation source was placed next to the test ovens to simulate the gamma field associated with spent fuel during dry storage. Gamma fields of approximately $12,000 \mathrm{R} / \mathrm{h}$ were calculated for the center of the $275^{\circ} \mathrm{C}$ oven, and gamma fields of $120,000 \mathrm{R} / \mathrm{h}$ were measured for the $380^{\circ} \mathrm{C}$ oven. The $16,000-\mathrm{cm}^{3}$ volume in the test oven contained $276 \mathrm{mg}$ of moisture at a $20^{\circ} \mathrm{C}$ dew point. The amount of axygen combined with this moisture $(0.17$ moles $\mathrm{O}_{2}$ ) is sufficient to oxidize approximately $13 \%$ of the approximately $95 \mathrm{~g}$ of spent fuel in the $275^{\circ} \mathrm{C}$ oven or approximately $7 \%$ of the approximately $170 \mathrm{~g}$ of spent fuel in the $380^{\circ} \mathrm{C}$ oven to $\mathrm{U}_{3} \mathrm{O}_{8}$. The specimens were periodically weighed to monitor oxidation and visually inspected for evidence of reaction (color change and powder formation). As shown in Tables 3 and 4 , weight changes were small or not measurable. There were no visible changes in appearance of the spent fuel fragments or the nonirradiated $\mathrm{UO}_{2}$ pellets. Spent fuel is very reactive with oxygen at $380^{\circ} \mathrm{C}$ and $\mathrm{U}_{3} \mathrm{O}_{8}$ forms in less than 1 h at $360^{\circ} \mathrm{C}$ (Einziger and Strain 1985). The differences in weight changes $1 \mathrm{~h}$ and $24 \mathrm{~h}$ after cooling at ambient temperature are attributed to moisture pickup by the $\mathrm{UO}_{2}$ during exposure to the hot cell atmosphere. 
TABLE 3. Results of Tests with Spent LWR Fuel in $275^{\circ} \mathrm{C}$ Moist Nitrogen Cover Gas $\left(20^{\circ} \mathrm{C}\right.$ dew point)

\begin{tabular}{|c|c|c|c|c|c|c|}
\hline Specimen (a) & Time, $h$ & Weight, $g$ & $\begin{array}{l}\text { Weight } \\
\text { Change, g }\end{array}$ & $\mathrm{CO}_{2}$, mol\% & $\mathrm{H}_{2}$, mol\% & $\mathrm{N}_{2}$, mol\% \\
\hline $3 A$ & 0 & 18.416 & 0 & $<0.01$ & $<0.01$ & 99.9 \\
\hline $3 B$ & 0 & 16.013 & 0 & $<0.01$ & $<0.01$ & 99.9 \\
\hline $3 C$ & 0 & 29.863 & 0 & $<0.01$ & $<0.01$ & 99.9 \\
\hline 30 & 0 & 30.705 & 0 & $<0.01$ & $<0.01$ & 99.9 \\
\hline $3 \mathrm{~A}$ & 432 & 18.413 & -0.003 & 0.22 & $<0.01$ & 99.6 \\
\hline $3 \mathrm{~B}$ & 432 & 16.010 & -0.003 & 0.22 & $<0.01$ & 99.6 \\
\hline $3 c$ & 432 & 29.756 & -0.007 & 0.22 & $<0.01$ & 99.6 \\
\hline $3 D$ & 432 & 30.703 & -0.002 & 0.22 & $<0.01$ & 99.6 \\
\hline $3 A$ & 1365 & 18.414 & -0.002 & 0.29 & 0.09 & 99.4 \\
\hline $3 B$ & 1365 & 16.010 & -0.003 & 0.29 & 0.09 & 99.4 \\
\hline $3 C$ & 1365 & 29.758 & -0.005 & 0.29 & 0.09 & 99.4 \\
\hline $3 D$ & 1365 & 30.707 & 0.002 & 0.29 & 0.09 & 99.4 \\
\hline
\end{tabular}

(a) $3 A-H . B$. Robinson bare spent fuel fragments

$3 B$ - bare nonirradiated pellets

$3 C$ - Point Beach bare spent fuel fragments

3D - Shippingport bare spent fuel fragments.

The bare fuel test results show a significant accumulation of $\mathrm{CO}_{2}$ in the test atmosphere. The $\mathrm{CO}_{2}$ was apparently released from the spent fuel during heating. The lack of reaction between the fuel and the $\mathrm{CO}_{2}$ is consistent with the positive free energy of reaction shown in Appendix $C$. 
TABLE 4. Results of Tests with Spent LWR Fuel in $380^{\circ} \mathrm{C}$ Moist Nitrogen Cover Gas $\left(31^{\circ} \mathrm{C}\right.$ dew point)

\begin{tabular}{|c|c|c|c|c|c|c|c|c|}
\hline Specimen ${ }^{(a)}$ & Time, $h$ & Welght, g & $\begin{array}{l}\text { Wight } \\
\text { Change, } g\end{array}$ & $\begin{array}{r}\mathrm{CO}_{2}, \\
\mathrm{mo} / \% \\
\end{array}$ & $\begin{array}{r}\mathrm{H}_{2}, \\
\mathrm{mo} / \mathrm{l} \\
\end{array}$ & $\begin{array}{r}\mathrm{N}_{2}, \\
\mathrm{mo} / \mathrm{s}\end{array}$ & $\begin{array}{l}\mathrm{O}_{2}, \\
\mathrm{~mol} / \% \\
\end{array}$ & $\begin{array}{r}\mathrm{CH}_{4}, \\
\mathrm{mo} / \mathrm{g} \\
\end{array}$ \\
\hline $\begin{array}{l}5-11 \\
5-12 \\
5-13 \\
5-14 \\
5-15 \\
5-16\end{array}$ & $\begin{array}{l}0 \\
0 \\
0 \\
0 \\
0 \\
0\end{array}$ & $\begin{array}{l}33.287 \\
23.668 \\
28.435 \\
30.026 \\
22.629 \\
29.277\end{array}$ & $\begin{array}{l}0 \\
0 \\
0 \\
0 \\
0 \\
0\end{array}$ & $\begin{array}{l}<0.01 \\
<0.01 \\
<0.01 \\
<0.01 \\
<0.01 \\
<0.01\end{array}$ & $\begin{array}{l}<0.01 \\
<0.01 \\
<0.01 \\
<0.01 \\
<0.01 \\
<0.01\end{array}$ & $\begin{array}{l}99.97 \\
99.97 \\
99.97 \\
99.97 \\
99.97 \\
99.97\end{array}$ & $\begin{array}{l}0.03 \\
0.03 \\
0.03 \\
0.03 \\
0.03 \\
0.03\end{array}$ & $\begin{array}{l}<0.01 \\
<0.01 \\
<0.01 \\
<0.01 \\
<0.01 \\
<0.01\end{array}$ \\
\hline $\begin{array}{l}5-11 \\
5-12 \\
5-13 \\
5-14 \\
5-15 \\
5-16\end{array}$ & $\begin{array}{l}505^{(b)} \\
505 \\
505 \\
505 \\
505 \\
505\end{array}$ & $\begin{array}{l}32.894 \\
23.281 \\
28.054 \\
30.030 \\
22.296 \\
29.276\end{array}$ & $\begin{array}{r}-0.393 \\
-0.387 \\
-0.381 \\
0.004 \\
-0.333 \\
0.000\end{array}$ & $\begin{array}{l}0.77 \\
0.77 \\
0.77 \\
0.77 \\
0.77 \\
0.77\end{array}$ & $\begin{array}{l}0.34 \\
0.34 \\
0.34 \\
0.34 \\
0.34 \\
0.34\end{array}$ & $\begin{array}{l}98.17 \\
98.17 \\
98.17 \\
98.17 \\
98.17 \\
98.17\end{array}$ & $\begin{array}{l}0.04 \\
0.04 \\
0.04 \\
0.04 \\
0.04 \\
0.04\end{array}$ & $\begin{array}{l}0.36 \\
0.36 \\
0.36 \\
0.36 \\
0.36 \\
0.36\end{array}$ \\
\hline $\begin{array}{l}5-11 \\
5-12 \\
5-13 \\
5-14 \\
5-15 \\
5-16\end{array}$ & $\begin{array}{l}505^{(e)} \\
505 \\
505 \\
505 \\
505 \\
505\end{array}$ & $\begin{array}{l}33.294 \\
23.684 \\
28.432 \\
30.032 \\
22.632 \\
29.278\end{array}$ & $\begin{array}{r}0.007 \\
0.016 \\
-0.003 \\
0.006 \\
0.003 \\
0.001\end{array}$ & $\begin{array}{l}0.77 \\
0.77 \\
0.77 \\
0.77 \\
0.77 \\
0.77\end{array}$ & $\begin{array}{l}0.34 \\
0.34 \\
0.34 \\
0.34 \\
0.34 \\
0.34\end{array}$ & $\begin{array}{l}98.17 \\
98.17 \\
98.17 \\
98.17 \\
98.17 \\
98.17\end{array}$ & $\begin{array}{l}0.04 \\
0.04 \\
0.04 \\
0.04 \\
0.04 \\
0.04\end{array}$ & $\begin{array}{l}0.36 \\
0.36 \\
0.36 \\
0.36 \\
0.36 \\
0.36\end{array}$ \\
\hline $\begin{array}{l}5-11 \\
5-12 \\
5-13 \\
5-14 \\
5-15 \\
5-16\end{array}$ & $\begin{array}{l}1104^{(b)} \\
1104 \\
1104 \\
1104 \\
1104 \\
1104\end{array}$ & $\begin{array}{l}33.296 \\
23.686 \\
28.445 \\
30.035 \\
22.638 \\
29.284\end{array}$ & $\begin{array}{l}0.009 \\
0.018 \\
0.010 \\
0.009 \\
0.009 \\
0.007\end{array}$ & $\begin{array}{l}0.59 \\
0.59 \\
0.59 \\
0.59 \\
0.59 \\
0.59\end{array}$ & $\begin{array}{l}0.16 \\
0.16 \\
0.16 \\
0.16 \\
0.16 \\
0.16\end{array}$ & $\begin{array}{l}98.45 \\
98.45 \\
98.45 \\
98.45 \\
98.45 \\
98.45\end{array}$ & $\begin{array}{l}0.02 \\
0.02 \\
0.02 \\
0.02 \\
0.02 \\
0.02\end{array}$ & $\begin{array}{l}0.38 \\
0.38 \\
0.38 \\
0.38 \\
0.38 \\
0.38\end{array}$ \\
\hline
\end{tabular}

(a) 5-11 - H. 8. Rablinson bare spent fuel fragments ( $N$-9B Section L4) 5-12 - H. B. Robinson bare spent fuel fragnents ( $N-98$ section $(3)$ 5-13 - Point Beach bare spent fuel fragments ("A" section 5-13, $63 \mathrm{~cm}$ above bottom end)

5-14 - Point Beach bare spent fuel fragments ("A" section 5-14, $58 \mathrm{~cm}$ above botton end)

5-15 - Shlppingport bare spent fuel fragments ("B" section 5-15 end plece)

5-16 - Shippingport bare spent fuel fragments "B" section 6-15 end piece).

(b) 1 to $4 \mathrm{~h}$ after cooling at amblent temperature.

(c) $24 \mathrm{~h}$ after cooling at amblent temperature. 


\section{DISCUSSION}

The effects of moisture in breached fuel rods on cladding integrity and spent fuel canisters have been evaluated (Woodley 1984). This report focuses on the thermodynamics of reactions between Zircaloy cladding and reactive constituents and between fuel at a cladding breach with the quantities of reactive constituents that could affect the spent fuel storage in nitrogen during 20 to 40 years of interim dry storage.

\section{THERMODYNAMICS OF URANIUM-OXYGEN COMPOUNDS}

Numerous studies have reported on the thermodynamics and phase diagrams for uranium-oxygen compounds. (a) The $0 / \mathrm{U}$ ratio for $\mathrm{UO}_{2}$ increases in an oxidizing environment with temperature-dependent rates. Key chemical reactions are presented in Appendix $A$. These chemical reactions are characterized by negative free energies of reaction, indicating that they are thermodynamically favorable. All of these reactions have been observed in the temperature regimes proposed for dry storage of spent LWR fuel. $\mathrm{U}_{3} \mathrm{O}_{7}$ and $\mathrm{U}_{4} \mathrm{O}_{9}$ have theoretical densities similar to or slightly greater than that for $\mathrm{v}_{2}\left(11.4 \mathrm{~g} / \mathrm{cm}^{3}\right.$ for $\mathrm{U}_{3} \mathrm{O}_{7}$ versus $10.97 \mathrm{~g} / \mathrm{cm}^{3}$ for $\left.\mathrm{UO}_{2}\right)$. Consequently, the oxidation products for those compounds do not lead to cladding degradation. However, $\mathrm{U}_{3} \mathrm{O}_{8}$ and $\mathrm{UO}_{3}$ have lower theoretical densities than $U_{2}\left(8.35 \mathrm{~g} / \mathrm{cm}^{3}\right.$ for $U_{3} O_{8}$ and $7.9 \mathrm{~g} / \mathrm{cm}^{3}$ for $\left.\mathrm{UO}_{3}\right)$. Sufficient formation of $\cup_{3} \mathrm{O}_{8}$ at the site of a breach in an $L W R$ fuel rod can produce permanent deformation of the cladding as well as crack formation and extension. Tests with bare spent fuel result in spalling of surface grains with high $0 / U$ ratios along grain boundaries, while the interior of the pellet grains remain at lower ratios of $0 / U$ because of slow solid state diffusion.

Since irradiated $\mathrm{UO}_{2}$ contains numerous fission products as impurities, its oxidation behavior may be significantly different from that of nonirradiated $\mathrm{UO}_{2}$ and may depend on burnup (Gilbert, White, and Knox 1985). Approximately

(a) Levin et al. 1964; Levin and McMurdie 1975; Roth et al. 1981; Samsonov 1973; Barin and Knacke 1973; Barin, Knacke, and Kubaschewski 1977; Stull and Prophet 1971; Wick and Block 1963; Wagman et al. 1982. 
2 at. $\%$ fissions of the fission products depend on the burnup and operating temperature of the fuel. The amount of fuel oxidation occurring during dry storage will impact the water solubility of the fuel and fuel performance during subsequent disposal in a repository.

\section{THERMOOYNAMICS OF REACTIONS BETWEEN URANIUM OXIOE AND WATER}

Reactions between the oxides of uranium and moisture have positive free energies of formation and are energetically unfavorable during dry storage (Appendix $C$ ). Therefore, the oxides of uranium would not react with moisture in a dry storage atmosphere where radiolysis of moisture is not a significant factor.

Radiolysis of moisture produces $\mathrm{H}_{2} \mathrm{O}_{2}$ as well as $\mathrm{H}_{2}$ and $\mathrm{O}_{2}$ (Denaro and Jayson 1972). The reactions of $\mathrm{H}_{2} \mathrm{O}_{2}$ and $\mathrm{O}_{2}$ with the oxides of uranium are energetically favorable in expected dry storage temperature ranges (Appendices $A$ and $E$ ). Even though $\mathrm{H}_{2} \mathrm{O}$ is not reactive with the oxides of uranium (Appendix $\mathrm{C}$ ), the formation of $\mathrm{H}_{2} \mathrm{O}_{2}$ and $\mathrm{O}_{2}$ would provide a potentially degrading oxidation reaction with spent LWR fuel at cladding breach sites, if concentrations were sufficiently high.

THERMOOYNAMICS OF REACTIONS BETWEEN OXIDES OF URANIUM AND $\mathrm{N}_{x} \mathrm{O}_{y}$

The free energies for the reactions of the oxides of uranium with $\mathrm{N}_{x} \mathrm{O}_{y}$ indicate that no reaction is expected with pure nitrogen (Appendix $D$ ). An evaluation was performed to determine the maximum acceptable operating temperature of $\mathrm{lO}_{2}$ in flowing nitrogen (Berry 1971; Levy and Foster 1961). The temperature 1 imit was predicted to be $1200^{\circ} \mathrm{C}$. The criteria for deriving this limit are not clear since formation of $\mathrm{UN}_{\mathrm{N}}$ from $\mathrm{UO}_{2}$ is associated with a positive free energy of formation of $157 \mathrm{kcal} / \mathrm{mole}$ of $\mathrm{UO}_{2}$ at $1200^{\circ} \mathrm{C}$ (Samsonov 1973).

The free energies of reaction for $\mathrm{NO}_{2}, \mathrm{NO}$, and $\mathrm{N}_{2} \mathrm{O}$ with $\mathrm{UO}_{2}$ are negative, indicating that reactions are favorabie. The presence of $\mathrm{NO}_{2}$ or a gamma field accelerated oxidation of $U_{2}$ pellets in air (Figures 4, 5, and 6). However, no reaction between moist nitrogen and either $\mathrm{wO}_{2}$ pellets or spent fuel fragments could be detected at temperatures from 225 to $380^{\circ} \mathrm{C}$ (Tables 2, 3, and 4). 
THERMODYNAMICS OF REACTIONS BETWEEN ZIRCONIUM AND NITROGEN COVER GAS

The free energies of reaction for zirconium with $\mathrm{O}_{2}, \mathrm{H}_{2} \mathrm{O}_{2}, \mathrm{~N}_{2} \mathrm{O}$, and $\mathrm{N}_{2}$ are negative; thus, the reactions are energetically favorable (Appendix $F$ ). However, the external spent fuel cladding surface is coated with $2 \mathrm{rO}_{2}$ that was formed during fuel manufacture or during exposure to reactor coolant prior to discharge (Johnson and Gilbert 1983a). Reaction of nitrogen with the protective $\mathrm{ZrO}_{2}$ coating is shown in Appendix $\mathrm{F}$ to be thermodynamically unfavorable. Consequently, little reaction is expected between nitrogen and the spent fuel cladding during dry storage. Accelerated oxidation of Zircaloy has been attributed to radiolytic-formed $\mathrm{H}_{2} \mathrm{O}_{2}$ in aqueous environments (Johnson 1977). However, this reaction is expected to be of little consequence in dry storage since the increase in $\mathrm{ZrO}_{2}$ thickness due to the reaction of the small inventory of $\mathrm{H}_{2} \mathrm{O}_{2}$ with the nearly 4 million $\mathrm{cm}^{2}$ of Zircaloy cladding surface area in a typical dry storage cask is negligible.

\section{APPLICATION OF RESULTS TO INTERIM DRY STORAGE OF SPENT FUEL IN NITROGEN}

Even though spent LWR fuel is not expected to react with nitrogen during dry storage, impurities and compounds formed by radiolysis of moisture contaminants are potentially reactive. The primary sources of water are:

- residual moisture remaining in the storage system after incomplete drying from pool loading operations

- release from water-logged reactor-breached fuel rods

- desorption of moisture from crud on the surface of fuel rods

- outgassing of storage component surfaces.

Results from the BWR Cask Characterization Test showed that the residual moisture remaining from pool loading operations, desorption of moisture from crud, and outgassing of storage component surfaces is less than $3 \mathrm{~g}$. The tests with reactor-breached whole rods at $\mathrm{BCL}$ indicated that the amount of moisture available from water-logged reactor-breached fuel rods after cask vacuum drying is less than $4 \mathrm{~g}$ per breached rod. Therefore, a dry storage cask containing 52 BWR $7 \times 7$ spent fuel assemblies with $0.1 \%$ fajled fuel rods (Garzarolli, von Jan, and Stehle 1979) would contain approximately three breached fuel rods ( $<12 \mathrm{~g}$ 
moisture) or a total moisture content of $<16 \mathrm{~g}$ after vacuum drying. The oxygen combined in this moisture is approximately $14 \mathrm{~g}$ or 0.4 moles of oxygen and could convert approximately $60 \mathrm{UO}_{2}$ pellets to $\mathrm{U}_{3} \mathrm{O}_{8}$ if all of the oxygen reacted with bare fuel at cladding breach sites. It is considerably more likely that the moisture would react with the Zircaloy cladding to produce a negligible increase in $\mathrm{ZrO}_{2}$ thickness.

The data base reviewed includes international shipping of spent fuel in nitrogen (shipping involving cask storage times up to several months), FRG and U.S. storage tests and demonstrations in moist nitrogen, and tests with bare fuel in moist nitrogen. None of these results indicated any reaction between spent fuel assemblies or bare fuel with nitrogen. The temperatures were sufficiently high that significant reactions would have resulted with the bare fuel in air. For example, during a test with spent fuel in nitrogen at $380^{\circ} \mathrm{C}$, air was inadvertently allowed to enter the oven. The spent fuel specimens were converted to a fine powder in less than 10 min.

The lack of reaction between $\mathrm{UO}_{2}$ and moist nitrogen may seem surprising since the free energy of reaction of $\mathrm{UO}_{2}$ with radiolysis products such as $\mathrm{N}_{2} \mathrm{O}$ and $\mathrm{NO}_{2}$ indicate that reactions are thermodynamically favorable. However, the oxidation potentiat of $\mathrm{UO}_{2}$ is reduced in the presence of moist nitrogen.

The oxygen potential of pure water vapor at pressure $\mathrm{po}_{\mathrm{H}_{2} \mathrm{O}}$ is calculated as shown below (calculations provided by D. R. 0lander, University of California).

Assuming water equilibrium according to:

$$
\mathrm{H}_{2}(\mathrm{~g})+1 / 2 \mathrm{O}_{2}(\mathrm{~g})=\mathrm{H}_{2} \mathrm{O}(\mathrm{g})
$$

yields

$$
K=\frac{\mathrm{P}_{\mathrm{H}_{2} \mathrm{O}}}{\left(\mathrm{P}_{\mathrm{H}_{2}}\right)\left(\mathrm{P}_{\mathrm{O}_{2}}\right)^{1 / 2}}=\exp (-\Delta \mathrm{Go} / \mathrm{RT})
$$

where $p_{i}$ is the partial pressure of species $i$ in the equilibrium gas and Go is the standard free energy of formation of water vapor: 


$$
\Delta G_{0}=-250.8+57.72\left(\mathrm{~T} / 10^{3}\right) \mathrm{kJ} / \mathrm{mole}
$$

At $200^{\circ} \mathrm{C}$, Go $=-223.5 \mathrm{~kJ} / \mathrm{mole}(54.1 \mathrm{kcal} / \mathrm{mole})$.

Neglecting the reaction of water with Zircaloy cladding or other components of the dry storage instaliation to calculate the maximum oxygen potential of the gas, material balances on oxygen and hydrogen yield:

$$
\begin{aligned}
& \mathrm{po}_{\mathrm{H}_{2} \mathrm{O}}=\mathrm{p}_{\mathrm{H}_{2} \mathrm{O}}+2 \mathrm{p}_{\mathrm{O}_{2}} \\
& \mathrm{po}_{\mathrm{H}_{2} \mathrm{O}}=\mathrm{p}_{\mathrm{H}_{2} \mathrm{O}}+\mathrm{p}_{\mathrm{H}_{2}}
\end{aligned}
$$

Equations (2), (4), and (5) can be solved for the oxygen partial pressure:

$$
\mathrm{Po}_{\mathrm{H}_{2} \mathrm{O}}=2 \mathrm{~K}\left(\mathrm{P}_{\mathrm{O}_{2}}\right)^{3 / 2}+2 \mathrm{p}_{0}
$$

Since the last term can be neglected because $K$ is very large,

$$
\mathrm{P}_{2}=\left(\mathrm{po}_{\mathrm{H}_{2} \mathrm{O}} / 2 \mathrm{~K}\right)^{2 / 3}
$$

the oxygen potential of the moist nitrogen is:

$$
\Delta G_{0_{2}}=R T \ln P_{0_{2}}
$$

The above simplified analysis provides the maximum oxygen potential of the moist nitrogen in the absence of radiolysis effects since it neglects the reaction with the Zircaloy cladding. Performing the above calculation for $200^{\circ} \mathrm{C}$ gives $-39 \mathrm{kcal} / \mathrm{mole}$ for the oxygen potential of moist nitrogen. According to the data listed for the first reaction in Appendix $A$, the oxygen potential of the two-phase $\mathrm{UO}_{2}-\mathrm{U}_{4} \mathrm{O}_{9}$ mixture is $0.5 \times-32 \mathrm{kcal} / \mathrm{mole}=-16 \mathrm{kcal} / \mathrm{mole}$. Since this value is larger than that calculated for moist nitrogen, moist nitrogen cannot thermochemically oxidize $\mathrm{UO}_{2}$ to $\mathrm{U}_{4} \mathrm{O}_{9}$. The equilibrium fuel stoichiometry based on an oxygen potential of $-39 \mathrm{kcal} / \mathrm{mole}$ at $200^{\circ} \mathrm{C}$ is $\mathrm{U}_{2} .006$ (01ander 1976). Consequently, reaction between the oxidants and the nearly 4 million $\mathrm{cm}^{2}$ of more accessible Zircaloy cladding would be more likely. 
Even though the quantity of reactants in a spent fuel storage installation containing nitrogen is not sufficient to cause significant degradation to the fuel assemblies, the effect of additional reactants introduced by inleakage of air should be considered. Storage casks are leak tested to a rate of not greater than $1 \times 10^{-6} \mathrm{~cm}^{3} / \mathrm{s}$ helium (GNS 1983). The corresponding leak rate for oxygen by Knudson flow (Dushman and Lafferty 1962) is approximately $3 \times$ $10^{-7} \mathrm{~cm}^{3} / \mathrm{s}$. At this rate, less than $0.2 \mathrm{~L}$ or 0.01 moles of oxygen would leak into the cask in 20 years. If this oxygen reacted with fuel at the site of a single cladding breach, no more than two fuel pellets would be oxidized to $\mathrm{U}_{3} \mathrm{O}_{8}$. Since this oxygen would be dispersed and would not react with fuel as a single breach site (the Zircaloy cladding offers approximately 4 million $\mathrm{cm}^{2}$ of reaction surface), the oxygen inleakage cannot be expected to produce significant fuel degradation. 
The following conclusions are made:

- A thermodynamic assessment of the compatibility of Zircaloy cladding and $\mathrm{UO}_{2}$ with pure nitrogen indicates that no chemical reactions are predicted during interim dry storage.

- Although Zircaloy cladding can thermodynamically react with impurity oxidants, moisture, and products of radiolysis, cladding degradation is expected to be negligible in the dry storage temperature regime. The small inventory of reactants plus the negligible oxygen inleakage cannot produce significant reaction layer thickness with the nearly 4 million $\mathrm{cm}^{2}$ of Zircaloy surface area in a BWR storage cask containing 52 spent fuel assemblies.

- Based on thermodynamic considerations, chemical reactions are possible between impurity oxidants $\left(\mathrm{O}_{2}\right.$ and radiolysis products such as $\mathrm{H}_{2} \mathrm{O}_{2}$ and $\mathrm{NO}_{2}$ ) in the storage system cover gas and $\mathrm{UO}_{2}$ exposed at cladding defects. However, the oxygen potential in moist nitrogen is in equilibrium with a fuel stoichiometry of $\mathrm{UO}_{2} .006$; and, therefore, low-density powders with stoichiometry of $\mathrm{UO}_{2} .67$ and above cannot form. Most oxidizing reactants would react with the very large, more reactive, accessible zircaloy cladding surface. Furthermore, the quantity of reactants expected in a dry storage system are insufficient to produce significant fuel degradation.

- Only a small amount of experimental data on the stability of $\mathrm{UO}_{2}$ in nitrogen is available. The limited experience dealing with the exposure of Zircaloy-clad fuel with nitrogen indicated that nitrogen is nonreactive with uranium oxide fuel, Zircaloy, and the oxide film on Zircaloy cladding.

- Tests on spent fuel fragments in moist nitrogen with a superimposed gamma irradiation field showed negligible weight gains and no changes in the physical appearance of the fuel specimens for up to 7 weeks at $275^{\circ} \mathrm{C}$ and $380^{\circ} \mathrm{C}$. 
- Tests with nonirradiated $\mathrm{UO}_{2}$ pellets in moist nitrogen and with a superimposed gamma irradiation field showed no measurable weight gain or change in the physical appearance of the $\mathrm{UO}_{2}$ pellets for times up to 7 weeks at $225^{\circ} \mathrm{C}, 250^{\circ} \mathrm{C}$, and $275^{\circ} \mathrm{C}$. 


\section{REFERENCES}

Barin, I., and 0. Knacke. 1973. Thermochemical Properties of Inorganic Substances. Springer-Verlag, New York.

Barin, I., 0. Knacke, and 0. Kubaschewski. 1977. Thermochemical Properties of Inorganic Substances. Supplement, Springer-Verlag, New York.

Berry, W. E. 1971. Corrosion in Nuclear Applications. The Electrochemical Society, Inc., John Wiley and Sons, Inc., New York.

Beyer, C. E., and C. R. Hann. 1977. BNWL-1956, Pacific Northwest Laboratory, Richland, Washington.

Boehm, H. H., and H. Foerch. 1985. "Operational Experience Gained with the Failed Fuel Rod Detection System in Nuclear Power Plants." Waste Managennent '85, Paper 15, Session VI, Tucson, Arizona.

Chin, B. A., and N. H. Madsen. 1983. "Deformation and Fracture Maps for Predicting the Failure Behavior of Spent Fuel Cladding." In Proceedings of Spent Fuel/Cladding Reaction During Dry Storage, August 17-18, 1983, Gaithersburg, Maryland, NUREG/CP-0049.

Croff, A. G. 1980. A User's Manua1 for the ORIGEN2 Computer Code. ORNL/TM-7175, Oak Ridge National Laboratory, Oak Ridge, Tennessee.

Cruickshank, A. 1985. "Repairing Fuel for Reinsertion." Nucl. Eng. International 30(371):19,20,23 (July 1985) (ISSN 0029-5507).

Daily, J. L. 1984. "Utility/DOE Nuclear Waste Policy Act Cooperative R\&D." Trans. ANS 46:99-100.

Denaro, A. R., and G. G. Jayson. 1972. Fundamentals of Radiation Chemistry. Ann Arbor Science Publishers, Inc.

Denovan, A. S., R. W. Ashley, and T. H. Longhurst. 1971. AECL-4063, Atomic Energy of Canada, Limited.

Dushman, S., and J. M. Lafferty. 1962. Scientific Foundations of Vacuum Technique, pp. 80-84.

Einziger, R. E., and J. A. Cook. 1983. "First Interin Examination of Whole Rod Tests at $230^{\circ} \mathrm{C} . "$ in Proceedings of Spent Fuel/Cladding Reaction During Dry Storage, August 17-18, 19833, Gaithersburg, Maryland, NUREG/CP-0049, pp. 39-69 and Appendix $C$.

Einziger, R. E., and R. V. Strain. 1985. "Effect of Cladding Defect Size on the Oxidation of Irradiated Spent Fuel Below $360^{\circ} \mathrm{C}$." In Proceedings of International Workshop on Irradiated Fuel Storage - Operating Experience and Devel= opment Programs, Toronto, Ontario, Canada. 
Ferrari, H. M. 1963. Nucl. Sci. Eng. 17:503.

Fleisch, J., K. Einfeld, and A. Luhrmann. 1982. "Long-Term Dry Storage Demonstration with Spent LWR Fuel." In Proceedings of Specialist Workshop on Techniques of Dry Storage of Spent Fuel Elements, May 11-13, 1982, Madrid, Spain.

Garzarolli, F., R. von Jan, and H. Stehle. 1979. "The Main Causes of Fuel Element Failure in Water-Cooled Power Reactors." Atom. Energy Rev. 17:31.

Gilbert, E. R., G. D. White, and C. A. Knox. 1985. "0xidation of U02 at 150 to $350^{\circ} \mathrm{C} . "$ In Proceedings of the International Workshop on Irradiated Fuel Storage - Operating Experience and DeveTopment Programs, Ontario Hydro,

Toronto, Canada.

Gi ibert, E. R., A. B. Johnson, Jr., and W. J. Bailey. 1985. "Review of Dry Spent Fuel Storage Experience." Presented at the Institute of Nuclear Materials Management Spent Fuel Storage Seminar, Washington D.C.

Gesellschaft fur Nuklear-service mbH (GNS). 1983. Topical Safety Analysis Report for the Castor IC Cask Independent Spent Fuel Storage Instajlation (Dry Storage). Essen, west Germany.

Johnson, A. B., Jr. 1977. Behavior of Spent Nuclear Fuel in Water Pool Storage. BNWL-2256, Pacific Northwest Laboratory, Richland, Washington.

Johnson, A. B., Jr., and E. R. Gilbert. 1983a. "Reaction of Fuel Cladding with Cover Gases Under Dry Storage Conditions." In Proceedings of Spent Fuel/ Cladding Reaction During Dry Storage, August 17-18, 1983, Gaithersburg, Maryland, NUREG/CP-0049, p. I-8.

Johnson, A. B., Jr., and E. R. Gilbert. 1983b. Technical Basis for Storage of Zircaloy-Clad Spent Fuel in Inert Gases. PNL-4835, Pacific Northwest Laboratory, Richland, Washington.

Johnson, A. B., Jr., et a1. 1983a. Behavior of Spent Nuclear Fuel and Storage System Components in Dry Interim Storage. PNL-4189, Rev. 1, Pacific Northwest Laboratory, Richland, Washington.

Johnson, A. B., Jr., et a1. 1983b. "Exposure of Breached BWR Fuel Rods at $325^{\circ} \mathrm{C}$ to Air and Argon." In Proceedings of Spent Fuel/Cladding Reaction During Dry Storage, August 17-18, 1983, Gaithersburg, Maryland, NUREG/CP-0049, P. E-2. Johnson, A. B., Jr., et al. 1985. "Simulated Dry Storage Test of a Spent PWR Nuclear Fuel Assembly in Air." Presented at Waste Management '85, Tucson, Arizona.

Kaspar, G., et a1. 1982. "Dry Storage of Instrumented Bundle Experiments." In Proceedings of Specialist Workshop on Techniques of Dry Storage of Spent FueT Elements, May 11-13, 1982, Madrid, Spain. 
Knox, C. A., E. R. Gilbert, and G. D. White. 1985. "An Experimental Program to Determine Maximum Temperatures for Dry Storage of Spent Fuel." Presented at Waste Management ' 85 , Tucson, Arizona.

Kohli, R., et al. 1985. "The Behavior of Breached Boiling Water Reactor Fuel Rods on Long-Term Exposure to Air and Argon at 598K." Nuc1. Tech. 69:186-197.

Levin, E. M., et al. 1964. Phase Diagrams for Ceramists. The American Ceramic Society, Columbus, Ohio.

Levin, E. M., and H. F. McMurdie. 1975. Phase Diagrams for Ceramists, 1975 Supplement. The American Ceramic Society, Columbus, Ohio.

Levy, A., and J. F. Foster. 1961. The Compatibility of Gas Coolants and Ceramic Materials in Coated-Particle Nuclear Fuels. BMI-1530, Battelle Memorial Institute, Columbus, Ohio.

Newman, D. F. 1985. "Spent Fuel Management: Near-Term Aspects." Mech. Eng. $107: 28-31$.

Olander, D. R. 1976. Fundamental Aspects of Nuclear Reactor Fuel Elements. Technical Information Center, Oak Ridge, Tennessee.

01 ander, D. R., D. Sherman, and M. Balooch. 1982. "Retention and Release of Water by Sintered Uranium Dioxide." J. Nuc1. Mater. 107:31-45.

Peehs, M., R. Kuhnel, and G. Kaspar. 1982. "Discussion of Spent LWR Fuel Properties in Relation to Actual Long-Term Storage Concepts." Presented at the International ENS/ANS Conference on New Direction in Nuclear Energy with Emphasis on the Fuel Cycle, April 26-30, 1982, Brussels, Belgium. Summary published in ANS Trans. 40:135.

Perry, R. H., and C. H. Chilton. 1973. Chemical Engineers' Handbook. 5th Edition, p. 3-235.

Roth, R. S., et a1. 1981. Phase Diagrams for Ceramists, Volume 5. American Ceramic Society, Columbus, Ohio.

Samsonov, G. V. 1973. The Oxide Handbook. IFI/Plenum, New York.

Spalaris, C. N., and F. H. Magerth. 1963. GEAP-4314, General Electric Company, Sunnyvale, California.

Stull, D. R., and H. Prophet. 1971. JANAF Thermochemical Tables. 2nd ed. NSRDS-B537.

Tokunaga, 0., et al. 1978. Radiat. Phys. Chem. 11:117.

Wagman, D. D., et al. 1982. "The NBS Tables of Chemical Thermodynamic Properties." J. Physical and Chemical Reference Data 11, Supplement No. 2. 
Waiton, L. A., et al. 1985. "Locating Leaking Fuel Rods in Light Water Reactors." Presented at the American Power Conference, April 1985, Chicago,

Illinois.

White, G. D., et al. 1983. "Oxidation of $\mathrm{UO}_{2}$ at 150 to $350^{\circ} \mathrm{C}$." In

Proceedings of Spent Fuel/Cladding Reaction Ouring Dry Storage, August 17-18, 1983, Gaithersburg, Maryland, NUREG/CP-0049.

wick, C.E., and F. E. Block. 1963. Thermodynamic Properties of 65 Elements Their Oxides, Halides, Carbides, and Nitrides. Bulletin 605, U.S. Bureau of Mines.

Woodley, R. E. 1984. Considerations Relevant to the Dry Storage of LWR Fuel Rods Containing Water. NUREG/CR-3658, HEDL-TME 84-14, Hanford Engineering Development Laboratory, Richland, Washington. 


\section{APPENDIX A}

THERMODYNAMICS OF CHEMICAL REACTIONS OF OXIDES OF URANIUM WITH OXYGEN AT $200^{\circ} \mathrm{C}$ 
THERMODYNAMICS OF CHEMICAL REACTIONS OF OXIDES OF URANIUM WITH OXYGEN AT $200^{\circ} \mathrm{C}$

\begin{tabular}{|c|c|}
\hline $\begin{array}{l}\text { Reactions and Free Energies of } \\
\text { Reactants and Products, kcal/mole }\end{array}$ & $\begin{array}{c}\text { Free Energy of Reaction, (a) } \\
\mathrm{kcal} / \mathrm{mole}\end{array}$ \\
\hline 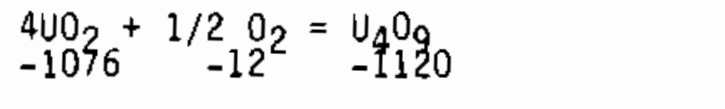 & -32 (Barin and Knacke 1973) \\
\hline $\begin{array}{ll}3 \mathrm{UO}_{2}+1 / 2 \mathrm{O}_{2}= & \mathrm{U}_{3} \mathrm{O}_{7} \\
-74 \mathrm{O} & -775\end{array}$ & $-35^{(b)}$ (Wagman et a 1. 1982) \\
\hline 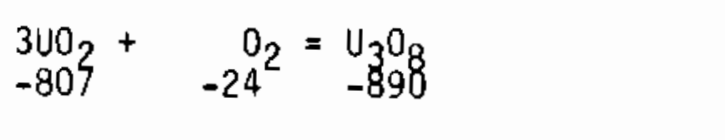 & -59 (Barin and Knacke 1973) \\
\hline 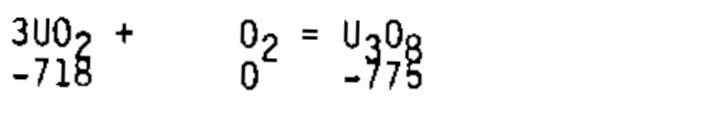 & -57 (Samsonov 1973) \\
\hline $\begin{array}{ll}\mathrm{U}_{3} \mathrm{O}_{7}+1 / 2 & \mathrm{O}_{2}= \\
-775 & \mathrm{U}_{3} \mathrm{O}_{8} \\
& -805\end{array}$ & 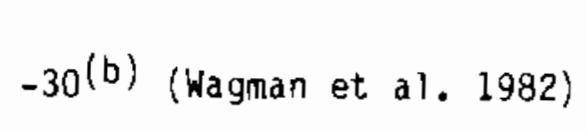 \\
\hline $\begin{aligned} \mathrm{U}_{3} \mathrm{O}_{8}+1 / 2 \mathrm{O}_{2} & =3 \mathrm{U} \mathrm{O}_{3} \\
-890 & -12\end{aligned}$ & -13 (Barin and Knacke 1973) \\
\hline $\begin{aligned} \mathrm{U}_{3} \mathrm{O}_{\mathrm{g}}+1 / 2 \mathrm{O}_{2}= & 3 \mathrm{U} \mathrm{O}_{3} \\
-775 & -789\end{aligned}$ & -14 (Samsonov 1973) \\
\hline $\begin{array}{l}\text { A negative free energy of rea } \\
\text { thermodynamically favorable. } \\
\text { b) } 25^{\circ} \mathrm{C} \text { temperature. }\end{array}$ & licates the reaction is \\
\hline
\end{tabular}


. 


\section{APPENDIX B}

CONCENTRATIONS OF FISSION PRODUCTS FROM 35,000 MWd/MTU PWR FUEL AT DISCHARGE AND 10 YEARS AFTER DISCHARGE 


\section{APPENDIX B}

CONCENTRATIONS OF FISSION PRODUCTS FROM 35,000 MWd/MTU PWR FUEL

AT DISCHARGE AND 10 YEARS AFTER DISCHARGE

\section{(Croff 1980)}

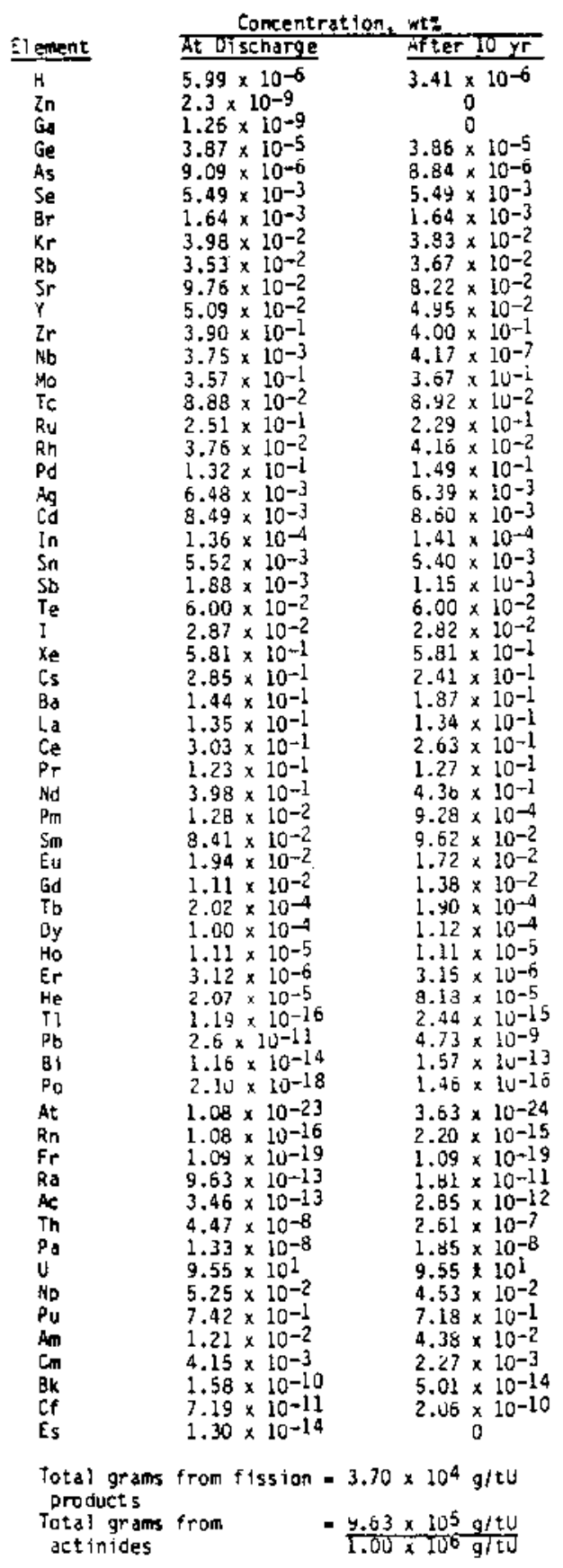

B. 1 



\section{APPENDIX C}

THERMODYNAMICS OF CHEMICAL REACTIONS BETWEEN OXIDES OF URANIUM AND $\mathrm{H}_{2} \mathrm{O}, \mathrm{CO}$, AND $\mathrm{CO}_{2}$ AT $200^{\circ} \mathrm{C}$ 
APPENDIX C

THERMODYNAMICS OF CHEMICAL REACTIONS BETWEEN OXIDES OF URANIUM AND $\mathrm{H}_{2} \mathrm{O}, \mathrm{CO}$ and $\mathrm{CO}_{2}$ AT $200^{\circ} \mathrm{C}$

Reactions and Free Energies of Reactants and Products, kcal/mole

$\begin{array}{lll}4 \mathrm{UO}_{2} & +\mathrm{H}_{2} \mathrm{O}=\mathrm{U}_{4} \mathrm{O}_{9}+\mathrm{H}_{2} \\ -1076 & -80 & -1120\end{array}$

$\begin{array}{llll}3 \mathrm{UO}_{2} \\ -740\end{array}+\mathrm{H}_{2} \mathrm{O}=\mathrm{U}_{3} \mathrm{O}_{7}+\mathrm{H}_{2}$

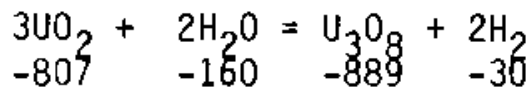

$\begin{array}{ll}\mathrm{UO}_{2}+ \\ -269\end{array}-\mathrm{H}_{2} \mathrm{O}=\mathrm{UO}_{3}+\mathrm{H}_{2}$

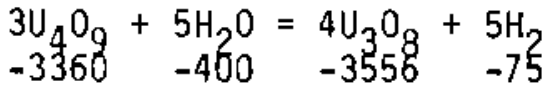

$\begin{array}{ll}\mathrm{U}_{3} \mathrm{O}_{7} \\ -775\end{array}+\underset{-55}{\mathrm{H}_{2} \mathrm{O}}=\underset{-805}{\mathrm{U}_{3} \mathrm{O}_{8}}+\frac{\mathrm{H}_{2}}{\mathrm{H}^{2}}$

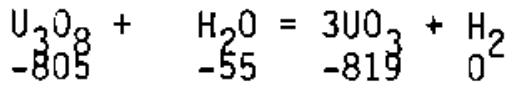

$\mathrm{UO}_{3}+$
-306

$\begin{array}{ll}\mathrm{UO}_{3} \\ -23_{3}\end{array}+\underset{-55}{\mathrm{H}_{2} \mathrm{O}=\mathrm{UO}_{3}} \cdot \underset{-333}{\mathrm{H}_{2} \mathrm{O}}$

$\begin{array}{ll}\mathrm{UO}_{3} \\ -2 \mathrm{H}_{3}\end{array}+\underset{-1 \mathrm{HO}}{2 \mathrm{H}_{2} \mathrm{O}}=\mathrm{UO}_{3} \cdot \underset{-3}{2 \mathrm{H}_{2} \mathrm{O}}$

$3 \mathrm{UO}_{2}+2 \mathrm{CO}=\mathrm{U}_{3} \mathrm{O}_{8}+2 \mathrm{C}$

$\begin{array}{llll}-807 & -96 & -889 & 308\end{array}$

$\begin{array}{ll}3 \mathrm{UO}_{2} \\ -807\end{array}+{ }_{-118}^{\mathrm{CO}_{2}}=\mathrm{U}_{3} \mathrm{O}_{8}+\underset{-889}{\mathrm{C}}+154$
Free Energy of Reaction, (a) $\mathrm{kcal} / \mathrm{mole}$

21 (Barin and Knacke 1973)

20 (b) (Wagman et al. 1982)

48 (Barin and Knacke 1973)

28 (Barin and Knacke 1973)

129 (8arin and Knacke 1973)

$25^{\text {(b) }}$ (Wagman et a 1.1982$)$ )

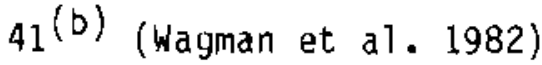

2 (Baron and Knacke 1973;

Barin, Knacke, and

Kubaschewski 1977)

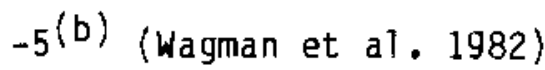

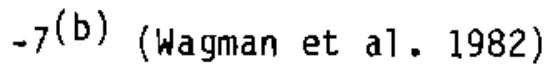

322 (Barin and Knacke 1973)

190 (Barin and Knacke 1973)

(a) A negative free energy of reaction indicates the reaction is thermodynamically favorable.

(b) $25^{\circ} \mathrm{C}$ temperature. 
APPENDIX D

THERMODYNAMICS OF CHEMICAL REACTIONS BETWEEN OXIDES OF URANIUM AND $\mathrm{N}_{\mathrm{x}} \mathrm{O}_{\mathrm{y}}$ AT $200^{\circ} \mathrm{C}$ 
Reactions and Free Energies of

Reactants and Products, $\mathrm{kcal} / \mathrm{mole}$

$\begin{array}{cc}\mathrm{UO}_{2}+ & 1 / 2 \mathrm{~N}_{2}= \\ -269 & \mathrm{UN}+\mathrm{O}_{2} \\ -11 & -78-24\end{array}$

$\underset{-269}{\mathrm{UO}_{2}}+\quad 1 / 2 \mathrm{NO}_{2}=\underset{-30}{\mathrm{UO}_{3}}+\underset{-6}{1 / 4} \mathrm{~N}_{2}$

$\mathrm{UO}_{2}+$
-269 $\quad \begin{aligned} & \mathrm{NO}= \\ & -3\end{aligned}$

$\begin{array}{ll}\mathrm{UO}_{2}+ \\ -259\end{array} \quad \mathrm{~N}_{2} \mathrm{O}=\mathrm{UO}_{3}+\mathrm{U}_{-6}+\mathrm{N}_{2}$

$\begin{aligned} & 3 \mathrm{UO}_{2} \\ & -807\end{aligned}+\underset{-20}{\mathrm{NO}_{2}}=\underset{-889}{-20}+\mathrm{U}_{3} \mathrm{O}_{8}+1 / 2 \mathrm{~N}_{2}$

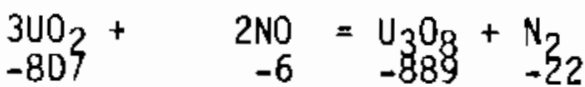

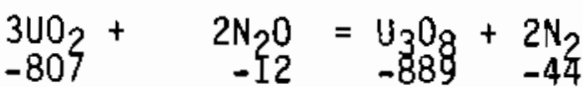

$\begin{array}{r}3 \mathrm{UO}_{2} \\ -807\end{array}+\underset{-17}{1 / 2} \mathrm{~N}_{2} \mathrm{O}_{4}={ }_{-889}^{\mathrm{U}_{3} \mathrm{O}_{8}}+\underset{-11}{1 / 2} \mathrm{~N}_{2}$

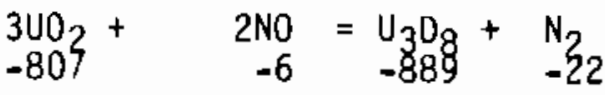

Free Energy of Reaction, (a)

$\mathrm{kcal} / \mathrm{mole}$

178 (Barin and Knacke 1973)

-33 (Barin and Knacke 1973)

-45 (Barin and Knacke 1973)

-53 (Barin and Knacke 1973)

-73 (Barin and Knacke 1973)

-98 (Barin and Knacke 1973)

-114 (Barin and Knacke 1973)

-76 (Barin and Knacke 1973)

-98 (Barin and Knacke 1973)

(a) A negative free energy of reaction indicates the reaction is thermodynamically favorable. 


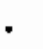




\section{APPENDIX E}

THERMODYNAMICS OF CHEMICAL REACTIONS BETWEEN $\mathrm{H}_{2} \mathrm{O}_{2}$ AND OXIDES OF URANIUM AT $200^{\circ} \mathrm{C}$ 


\section{THERMDOYNAMICS OF CHEMICAL REACTIONS BETWEEN $\mathrm{H}_{2} \mathrm{O}_{2}$}

\section{AND OXIDES OF URANIUM AT $200^{\circ} \mathrm{C}$}

Reactions and Free Energies of Reactants and Products, kcal/mole

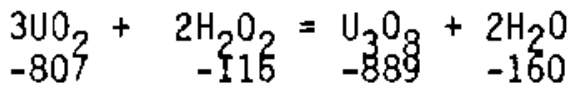

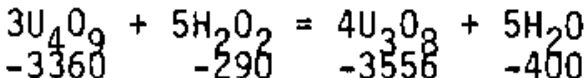

$\begin{aligned} & \mathrm{U}_{3} \mathrm{O}_{7} \\ & -775\end{aligned}+\mathrm{H}_{2} \mathrm{O}_{2}={ }_{-25} \mathrm{U}_{30} \mathrm{O}_{8}+{ }_{-805}+\mathrm{H}_{25} \mathrm{O}$
Free Energy of Reaction, (a) $\mathrm{kcal} / \mathrm{mole}$

-126 (Barjn and Knacke 1973)

-306 (Barin and Knacke 1973)

$-60^{(b)}$ (Wagman et al. 1982)

(a) A negative free energy of reaction indicates the reaction is thermodynamically favorable.

(b) $25^{\circ} \mathrm{C}$ temperature. 
-

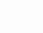




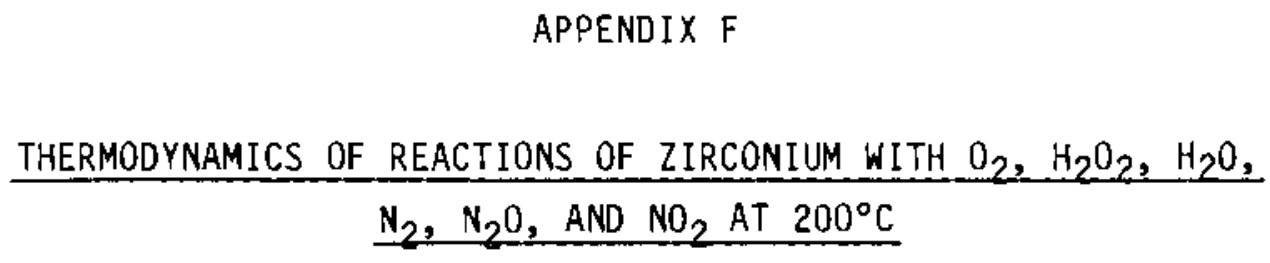




\section{APPENDIX $F$}

THERMODYNAMICS OF REACTIONS OF ZIRCONIUM WITH $\mathrm{O}_{2}, \mathrm{H}_{2} \mathrm{O}_{2}, \mathrm{H}_{2} \mathrm{O}$, $\mathrm{N}_{2}, \mathrm{~N}_{2} \mathrm{O}$, AND $\mathrm{NO}_{2}$ AT $200^{\circ} \mathrm{C}$

Reactions and Free Energies of Reactants and Products, kcal/mole

$\begin{array}{ll}\mathrm{Zr}+ & \mathrm{O}_{2}= \\ -5 & \mathrm{ZrO} \mathrm{O}_{2} \\ -24 & -269\end{array}$

$\underset{-5}{\mathrm{Zr}}+\underset{-\mathrm{I} \mathrm{H}_{2}}{2 \mathrm{H}_{2} \mathrm{O}_{2}}=\underset{-269}{\mathrm{Z} \mathrm{rO}_{2}}+\underset{-160}{2}$

$\begin{array}{ll}\mathrm{Zr}+ \\ -5\end{array}-\underset{-16}{2 \mathrm{H}_{2} \mathrm{O}}=\underset{-269}{\mathrm{Z} r \mathrm{O}_{2}}+\underset{-30}{2}+\mathrm{H}_{2}$

$\mathrm{Zr}+1 / 2 \mathrm{~N}_{2}=\mathrm{ZrN}$

$-5 \quad-11^{2}-92$

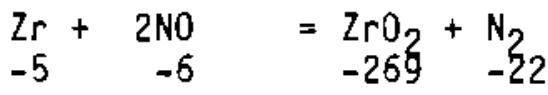

$\underset{-5}{\mathrm{Zr}+2 \mathrm{~N}_{2} \mathrm{O}}-\frac{12}{-12}=\underset{-269}{\mathrm{Zr} \mathrm{O}_{2}}+\underset{-44}{2 \mathrm{~N}_{2}}$

$\underset{-5}{\mathrm{Zr}}+\underset{-20}{\mathrm{NO}_{2}}=\underset{-269}{2 \mathrm{Z} \mathrm{O}_{2}}+1 / 2 \mathrm{~N}_{2}$

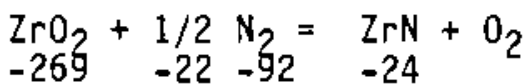

Free Energy of Reaction, (a) $\mathrm{kcal} / \mathrm{mole}$

-240 (Barin and Knacke 1973)

-308 (Barin and Knacke 1973)

-134 (Barin and Knacke 1973)

-76 (Barin and Knacke 1973)

-280 (Barin and Knacke 1973)

-296 (Barin and Knacke 1973)

-255 (Barin and Knacke 1973)

175 (Barin and Knacke 1973)

(a) A negative free energy of reaction indicates the reaction is thermodynamically favorable. 


\section{.}




\section{DISTRIBUTION}

No. of

Copjes

OFFSITE

R. Bown

Office of Civilian Radioactive Waste Management

U.S. Department of Energy

RW-30

Washington, DC 20545

3. Epstein

Office of Civilian Radioactive Waste Management

U.S. Department of Energy

Washington, DC 20545

J. R. Hilley

Office of Civilian Radioactive Waste Management

U.S. Department of Energy

$\mathrm{RW}-30$

Washington, DC 20545

K. A. Klein

Office of Civilian Radioactive Waste Management

U.S. Department of Energy

RW-31

Washington, DC 20545

0 . E. Shelor

Office of Civilian Radioactive Waste Management

U.S. Department of Energy

RW-32

Washington, DC 20545

W. Stringfield

Office of Civilian Radioactive Waste Management

U.S. Department of Energy

Washington, DC 20545
No. of

Copies

J. S. Finucane

Energy Information Administration

U.S. Department of Energy

EI-53

Washington, DC 20545

K. G. Golliher

U.S. Department of Energy

Albuquerque Operations Office

Albuquerque, NM 87115

C. P. Gertz

U.S. Department of Energy

Idaho Operations office

550 Second Street

Idaho Falls, I0 83401

D. Vieth

U.S. Department of Energy

Nevada Operations office

Las Vegas, NV 89114

C. Matthews

U.S. Department of Energy

Oak Ridge Operations office

P.0. Box E

Oak Ridge, TN 37830

30 DOE Technical Information Center

B. A. Chin

Mechanica\} Engineering Dept.

247 Wilmore Laboratories

Auburn University, AL 36830

M. Sankovich

Babcock \& Wilcox Co.

P.0. Box 1260

Lynchburg, VA 24505 
No. of

Copies

L. A. Walton
Babcock \& Wilcox Co.
P.0. Box 10935
Lynchburg, VA 24506
P. A. File
Baltimore Gas and Electric Co.
Calvert Cliffs Nuclear Power
Plant
Lusby, MO 20657
J. A. Carr
Battelle Columbus Laboratories
Office of Nuclear
Waste Isolation
505 King Avenue
Columbus, OH 43201

B. A. Rawles

Battelle Memorial Institute

Office of Nuclear Waste

Isolation

505 King Avenue

Columbus, $\mathrm{OH} 43201$

10 T. W. Wood

Battelle Memorial Institute

Washington Operations

2030 M Street-NW

Suite 800

Washington, DC 20036

G. A. Townes

BE Inc.

P.0. Box 145

New Ellenton, SC 29B09

R. L. Hails

Bechtel Power Corporation

15740 Shady Grove Rd.

Gaithersburg, MD 20760

D. R. 01 ander

University of California

647 San Fernando Ave.

Berkeley, CA 94707
No. of

Copies

R. Kunita

Carolina Power \& Light Co.

P.0. Box 1551

Raleigh, NC 27602

G. C. Jobson

Chem-Nuclear Systems, Inc. One Greystone West Building

240 Stoneridge Drive, Suite 100

Columbia, SC 29210

N. Fuhrman

Combustion Engineering, Inc. 1000 Prospect Hill Road

windsor, CT 06095

R. L. Moscardini

Combustion Engineering, Inc. 1000 Prospect Hill Road

Windsor, CT 06095

G. P. Wagner

Commonwealth Edison

Nuclear Stations Division

P.0. Box 767

Chicago, IL 60690

T. J. Marz

Consumers Power Company

1945 W. Parnall Road

Jackson, MI 49201

S. J. Raffety

Dariland Power Coop.

LaCrosse, WI 54601

R. W. Rasmussen

Duke Power Company

P.0. Box 33189

Charlotte, NC 28242

R. Stanford

Edison Electric Institute

1111 19th St., NW

Washington, DC 20036 
No. of

Copies

D. H. Schoonen

EG\&G Idaho, Inc.

P.0. Box 1625

Idaho Falls, ID 83415

R. F. Williams

Electric Power Research Institute

P.0. Box 10412

Palo Alto, CA 94303

R. W. Lambert

Electric Power Research Institute

P.0. Box 10412

Palo Alto, CA 94303

J. R. Tomonto

Florida Power \& Light

P.0. Box 013100

Miami, FL 33101

G. T. Zamry

Florida Power \& Light Co. 9250 W. Flagler St.

Miami, FL 33174

B. J. Baxter

GA Technologies Inc. P.0. Box 81608

San Diego, CA 92138

E. E. Voiland

General Electric Co.

Morris Operation

Morris, IL 60450

W. L. Dobson

Gilbert Associates, Inc.

P.0. Box 1498

Reading, PA 19603

V. J. Barnhart

GNSI

135 Darling Dr.

Avon, CT 06001
No. of

Copies

B. Handly

Houston Lighting \& Power Co.

Nuclear Fuels, Baybrook

P.0. Box 1700

Houston, TX 77001

J. A. McBride

E. R. Johnson Associates, Inc. 11702 Bowman Green Drive

Reston, VA 22090

L. M. Irosten

LeBoeuf, Lamb, Leiby, \& MacRae

1333 New Hampshire Ave. NW

Washington, DC 20036

L. D. Ramspott

Lawrence Livermore National Laboratory

P.0. Box 808

Mail Stop L404

Livermore, CA 94550

V. M. Oversby

Waste Package Task, NNWSI

Lawrence Livermore National Laboratory

P.0. Box 808

L206

Livermore, CA 94550

J. H. Garrity

Maine Yankee Atomic Power Co. Edison Drive

Augusta, ME 04336

G. 0. Whittier

Maine Yankee Atomic Power Co. Edison Drive

Augusta, ME 04336

R. Whale

Michigan Public Service

Commission

6545 Mercantile Way

Lansing, MI 48909 
No. of

Copies

R. Calabro

Northeast Utilities Service Co. P.0. Box 270

Hartford, CT 06101

R. Isakson

Northeast Utilities Service Co. P.0. Box 270

Hartford, CT 06101

E. Krinick

Northeast Utilities Service Co.

P.0. Box 270

Hartford, CT 06101

M. T. Pitek

Northeast Utilities Service Co.

P.0. Box 270

Hartford, CT 06101

3. Houston

Nuclear Assurance Corp. 5720 Peachtree Parkway

Norcross, GA 30092

J. M. Viebrock

Nuclear Assurance Corp. 5720 Peachtree Parkway

Norcross, GA 30092

J. Clark

Nuclear Fuel Services

6000 Executive Blyd.

Rockville, MD 20852

R. T. Haelsig

Nuclear Packaging Inc. 1010 S. 336th St.

Federal Way, WA 98003

G. J. Antonucci

NUS Corporation

910 Clopper Rd.

Gaithersburg, MD 20878
No. of

Copies
J. V. Massey

NUTECH Engineers

145 Martinvale Lane

San Jose, CA 95119

J. Van Cleve

Oak Ridge National Laboratory

P.0. Box $X$

Oak Ridge, TN 37831

M. Litterman

Pacific Gas \& Electric,

Trojan Fuel

121 S.W. Salmon St.

Portland, OR 97204

M. L. Picklesimer

Pic Products Co.

221 Meadowood Lane

Monteve110, AL 35115

Portland General Electric

131 S.W. Salmon Street

Portland, OR 97204

G. C. Allen

Sandia National Laboratory

Transporation Technology Center

P.0. Box 5800

ATbuquerque, NM 87185

J. F. Ney

Sandia National Laboratory

Transporation Technology Center

P.0. 80x 5800

Albuquerque, NM 87185

E. Kuhns

Stone and Webster Engineering Corp.

1 Penn Plaza

250 W. 34th St.

New York, NY 10119

J. B. Moegling

Tennessee Valley Authority

404 Krystal Building

Chattanooga, TN 37401 
No. of Copies

E. Gordon

Transnuctear, Inc.

507 Newmark Esplanade

Rockville, MD 20850

J. Mangusi

Transnuclear, Inc.

$1 \mathrm{~N}$. Broadway

White Plains, NY 10601

B. R. Teer

Transnuclear, Inc.

1 N. Broadway

White Plains, NY 10601

C. E. King

Uranium Mgt. Corp.

310 DeGuigne Drive

Sunnyvale, CA 94086

T. Cotton

Office of Technology Assessment

U.S. Congress

Washington, DC 20510

N. H. Davison

U.S. Nuclear Regulatory Commission

Office of Nuclear Materials Safety and Safeguards

Washington, DC 20555

C. Feldman

U.S. Nuclear Regulatory Commission

Office of Nuclear Regulatory Research

Washington, DC 20555

J. Roberts

U.S. Nuclear Regulatory Commission

Office of Nuclear Materials Safety and Safeguards

Washington, DC 20555
No. of

Copies

L. C. Rouse

U.S. Nuclear Regulatory Commission

Spent Fuel Storage Installation

Division of Fuel Cycle and

Material Safety

Washington, DC 20555

S. P. Ture]

U.S. Nuclear Regulatory Commission

Office of Nuclear Regulatory Research

Washington, DC 20555

W. J. Wachter

U.S. Tool and Die, Inc. 4030 Route 8

Allison Park, PA 15101

S. P. Keck

Virginia Electric \& Power

P.0. Box 26666

Richmond, VA 23261

M. L. Smith

Virginia Electric \& Power

P.0. Box 26666

Richmond, VA 23261

J. A. Nevshemal

Westec Services, Inc.

P.0. Box 765

Muscatine, IA 52761-0765

E. A. Bassler

Westinghouse Electric Corp.

Box 2728

Pittsburgh, PA 15230

A. R. Hak I

Westinghouse Electric Corp. Waste Technology Services Div. P. 0. Box 10864

Pittsburgh, PA 15236 
No. of

Copies

J. B. Wright

Westinghouse Electric Corp.

P.0. Box 708

Mercury, NV 89023

N. Dayem

R. F. Weston Co. 2301 Research Blvd.

Rockville, MD 20850

E. Benz

R. F. Weston Co.

2301 Research Blvd.

Rockville, MD 20850

\section{ONSITE}

7 DOE Richland Operations Office

G. J. Bracken

P. A. Craig (4)

D. C. Langstaff

M. J. Plahuta

3 Hanford Engineering Development Laboratory

R. E. Einziger

R. L. Knecht

$R$. E. Woodley
No. of

Copies

Rockwell Hanford Company

C. L. Brown

63 Pacific Northwest Laboratory

M. J. Apted

W. J. Bailey

G. H. Beeman

B. M. Cole

J. M. Creer

S. K. Edler

M. D. Freshley

E. R. Gilbert (20)

R. J. Guenther

R. J. Hall

P. E. Hart

J. N. Hol loway

A. B. Johnson, Jr. (5)

C. A. Knox

D. K. Kreid

M. R. Kreiter

J. L. McElroy

G. L. MeVay

L. G. Morgan

0 . F. Newman

0 . R. Oden

J.T.A. Roberts

K. J. Schnejder

G. D. White

Publishing Coordination (2)

Technical Information (5) 